University of Pennsylvania Carey Law School

Penn Law: Legal Scholarship Repository

Faculty Scholarship at Penn Law

2007

\title{
The Uneasy Entente Between Insanity and Mens Rea: Beyond
}

\section{Clark v. Arizona}

Stephen J. Morse

University of Pennsylvania Carey Law School

Morris B. Hoffman

District Judge, Second Judicial District (Denver), State of Colorado.

Follow this and additional works at: https://scholarship.law.upenn.edu/faculty_scholarship

Part of the Constitutional Law Commons, Criminal Law Commons, Ethics and Political Philosophy Commons, Law and Psychology Commons, Neurosciences Commons, and the Psychiatry and Psychology Commons

\section{Repository Citation}

Morse, Stephen J. and Hoffman, Morris B., "The Uneasy Entente Between Insanity and Mens Rea: Beyond Clark v. Arizona" (2007). Faculty Scholarship at Penn Law. 137.

https://scholarship.law.upenn.edu/faculty_scholarship/137

This Article is brought to you for free and open access by Penn Law: Legal Scholarship Repository. It has been accepted for inclusion in Faculty Scholarship at Penn Law by an authorized administrator of Penn Law: Legal Scholarship Repository. For more information, please contact PennlawIR@law.upenn.edu. 


\section{THE UNEASY ENTENTE BETWEEN LEGAL INSANITY AND MENS REA: BEYOND CLARK V. ARIZONA}

\section{STEPHEN J. MORSE* \& MORRIS B. HOFFMAN**}

This Article considers the meaning and relation of legal insanity and mens rea, using the Supreme Court's recent decision, Clark v. Arizona, which addressed both, as the focus of discussion. It suggests that rules limiting the introduction of evidence of mental disorder to negate mens rea are unjust and that fair blame and punishment require retaining an insanity defense. Alternatives to the insanity defense are rejected because they are analytically unconvincing or unfair. The Article also addresses recent challenges to the very possibility of criminal responsibility that are based on new discoveries in neuroscience and behavioral science. It concludes that these challenges are conceptually, empirically, and normatively unjustified. Finally, it proposes that legal insanity cannot be consensually defined morally or scientifically, but that the human capacity for rationality is the key to the normative debate about responsibility.

- Ferdinand Wakeman Hubbell Professor of Law and Professor of Psychology and Law in Psychiatry, University of Pennsylvania. This paper was first presented at a workshop at the University of Pennsylvania. I thank my colleagues for their excellent comments. I specially thank Ed Greenlee for his invaluable help. As always, my personal attorney, Jean Avnet Morse, provided sound, sober counsel and moral support.

* District Judge, Second Judicial District (Denver), State of Colorado. The views expressed here do not necessarily reflect the views of the Second Judicial District or any of my colleagues on that Court. I want to thank my interns from the University of Colorado School of Law, Edward Hafer and Cameron Munier, for their research and editing help. 
C. MENS REA

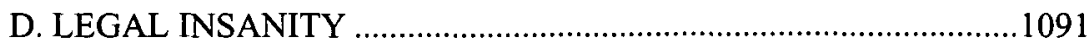

E. MENS REA AND LEGAL INSANITY ………………..................1096

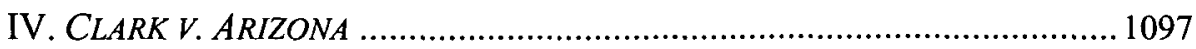

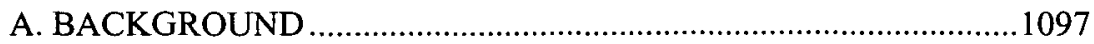

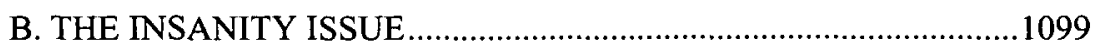

C. THE MENS REA ISSUE ...............................................................1101

1. The Tripartite Evidence Construction .................................1102

2. The Channeling Argument …………………………….........1105

V. THE CONSTITUTIONALITY AND WISDOM OF ABOLISHING MENS

REA AND LEGAL INSANITY .....................................................1111

A. ABOLISHING MENS REA ..........................................................1111

B. ABOLISHING THE INSANITY DEFENSE ……………................1115

C. ALTERNATIVES TO ABOLITION.................................................1121

VI. THE FUTURE OF MENS REA AND LEGAL INSANITY ..........................1132

A. THE GENERAL CHALLENGE TO RESPONSIBILITY ..................1132

B. THE ROOTS OF RESPONSIBILITY ..............................................1143

VII. MENS REA, LEGAL INSANITY, AND COMMON SENSE .........................1146

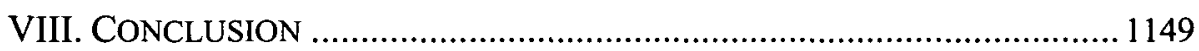

\section{INTRODUCTION}

Ever since the affirmative defense of insanity took its first truly modern breath in 1843 in M'Naghten's Case, ${ }^{1}$ its relationship to its cousin, mens rea, ${ }^{2}$ has been plagued with confusion. How can one be "insane" yet

\footnotetext{
${ }^{1}$ (1843) 8 Eng. Rep. 718 (H.L.).

2 "Mens rea" is Latin for "guilty mind." The phrase comes from the English legal precept "Actus non facit reum nisi mens rea sit" ["An act is not guilty unless the mind is guilty"], which dates from at least the time of Henry I in the early 1100 s, and which was likely based on the writings of St. Augustine. See generally Francis Bowes Sayre, Mens Rea, 45 Harv. L. Rev. 974, 974 (1932); Paul Robinson, Mens Rea, University of Pennsylvania, Scholarship at Penn Law, Paper No. 35 (1999), available at $\mathrm{http} / / /$ lsr.nellco.org/upenn/wps/papers/35. Virtually every civilization that has left a relevant record-including the Babylonians, Jews, Egyptians, Greeks, and Romans-recognized that the law must judge both the act and the intention. See Max Radin, Intent, Criminal, in 8 ENCYClOPAedia OF THE SOCIAL SCIENCES 126 (Edwin R. A. Seligman \& Alvin Johnson eds., 1932). This general rule had some strict liability exceptions, such as the common ancient rule that a man was strictly liable for the acts of his slaves, and even a strict liability view of homicide. See 2 Sir Frederick Pollock \& Frederick William Maitland, The History OF ENGLISH LAW 470-73 (2d ed. 1968). These exceptions did not displace the rule that even
} 
still have the mental state element required by the definition of a particular crime? Can mens rea alone be a sufficient basis for a sensible theory of criminal responsibility? Are there constitutional limits to a state's power to eliminate or restrict the insanity defense or the mens rea requirement? May states constitutionally preclude defense evidence directly relevant to insanity or lack of mens rea? More generally, what impact should recognized mental disorders have on criminal responsibility? Should evolving ideas about the nature and causes of mental disorders and of human behavior in general require changes in our settled views of blameworthiness?

In Clark v. Arizona, ${ }^{3}$ the Supreme Court recently had one of its rare opportunities to clarify some of these issues. ${ }^{4}$ The questions Clark presented were whether Arizona's unusually narrow insanity defense test violated the defendant's substantive due process rights and whether an Arizona rule that excluded virtually all expert evidence concerning mental disorder offered for the purpose of negating mens rea violated procedural due process. ${ }^{5}$ Alas, the decision clarified little and may in fact have further muddied the conceptual and practical waters. ${ }^{6}$

in ancient times civilized people cared both about the wrongdoer's acts and his intentions. Indeed, the notion that punishable crimes must be non-accidental appears to be a human universal. See infra text accompanying note 185. But see Guyora Binder, The New Culpability: Motive, Character, and Emotion in Criminal Law, 6 BUfF. CRIM. L. REv. 1, 15 (2002) ("[T]he supposedly ancient conception of mens rea ... is really a modern polemical construct.").

3 126 S. Ct. 2709 (2006).

4 Throughout its history, the Court has decided only a handful of cases dealing with broad concepts of criminal responsibility, a reticence that reflects the institutional presumption that these questions are largely for the states to decide. See infra text accompanying note 12 . Clark was the Court's first case dealing directly with insanity or the general question of mens rea since 1996. See discussion of Montana v. Egelhoff, 518 U.S. 37 (1996), infra in the text accompanying notes 36-48. There were mental state cases decided by the Court in the period between Egelhoff and Clark, but they all dealt either with collateral issues or with a specific type of mens rea. See, e.g., Roper v. Simmons, 543 U.S. 551 (2005) (holding that execution of person who committed capital murder prior to eighteen years of age violates Eighth Amendment); Atkins v. Virginia, 536 U.S. 304 (2002) (holding that execution of mentally retarded defendant violates Eighth Amendment); Kansas v. Crane, 534 U.S. 407 (2002) (addressing constitutional limits on states' civil commitment powers); Holloway v. United States, 526 U.S. 1 (1999) (holding that the intent requirement of federal car-jacking statute satisfied by defendant's "conditional intent" to harm driver if necessary); Kansas v. Hendricks, 521 U.S. 346 (1997) (addressing constitutional limits on states' civil commitment powers).

${ }^{5}$ Clark, 126 S. Ct. at 2716.

${ }^{6}$ See Ronald J. Allen, Clark v. Arizona: Much (Confused) Ado About Nothing, 4 Онюо ST. J. CRIM. L. 135 (2006); Peter Westen, The Supreme Court's Bout with Insanity: Clark v. Arizona, 4 OHı ST. J. CRIM. L. 143 (2006). Professors Allen and Westen characterize the issues in Clark differently than this Article-especially Professor Allen, who thinks that the 
To lay the foundation for understanding Clark, in Parts II and III we first examine the law of criminal responsibility, including its constitutional dimensions, and then explore the relevance of mental disorder to wellsettled principles of criminal responsibility, such as the formation of mens rea and the criteria for the defense of insanity. Part IV considers Clark in detail. Part $\mathrm{V}$ addresses the constitutionality and wisdom of abolishing either the requirement of mens rea or the defense of legal insanity. Part VI considers the future of these two doctrines, both of which, we contend, are central to preserving just and sensible principles of blameworthiness. We conclude that contemporary scientific approaches to understanding human behavior do not undermine these principles and our legal practices based on them.

\section{CRIMINAL RESPONSIBILITY AND THE CONSTITUTION}

The structure of criminal responsibility is superficially straightforward. Crimes are defined by their "elements," which always include a prohibited act and in most cases a mental state, a mens rea, such as intent. The Constitution's Due Process Clause has been construed to require that the prosecution must prove all the elements defining a criminal offense beyond a reasonable doubt. ${ }^{7}$ Even if the state can prove all the elements beyond a reasonable doubt, the defendant may avoid criminal liability by establishing an affirmative defense of justification or excuse. ${ }^{8}$ The Due Process Clause has been interpreted to permit a state to place the burden of persuasion for affirmative defenses on either the prosecution or the defense. ${ }^{9}$

opinion concerns a simple issue of evidence-but both agree that the opinion failed to clarify legal insanity, mens rea, and the relation between them.

${ }^{7}$ In re Winship, 397 U.S. 358, 364 (1970) ("[T]he Due Process Clause protects the accused against conviction except upon proof beyond a reasonable doubt of every fact necessary to constitute the crime with which he is charged."); see also Sandstrom v. Montana, 442 U.S. 510 (1979) (noting jury instruction shifting burden of persuasion on a mental state element to defendant violates due process).

${ }^{8}$ The border between justification and excuse can be hazy. See Kent Greenawalt, The Perplexing Borders of Justification and Excuse, 84 CoLUM. L. REv. 1897 (1984). Nevertheless, the distinction between clear cases may be stated as follows: conduct that would otherwise be criminal is justified if it is right or at least permissible under the specific circumstances. Self-defense is the classic example. Conduct is excused, even if it is wrongful, if the defendant was not responsible for the conduct. Infancy and legal insanity are classic examples.

${ }^{9}$ See Dixon v. United States, 126 S. Ct. 2437 (2006) (permitting placing burden of persuasion for duress on defendant); Martin v. Ohio 480 U.S. 228 (1987) (permitting placing of burden of persuasion for self-defense on defendant); Leland v. Oregon, 343 U.S. 790 (1952) (permitting placing burden of persuasion for legal insanity on defendant). It appears that a jurisdiction may place the burden of persuasion on the defendant at any level it wishes, ranging from a preponderance of the evidence to beyond a reasonable doubt. In most cases, however, jurisdictions that shift the burden of persuasion to the defense require that the 
Persistent confusion about the meaning of mens rea, as well as deep and complex constitutional issues, cloud this facially straightforward account of criminal responsibility. First, let us clarify some terminological confusion. In its narrow sense, mens rea refers to the specific mental state or states required by the definition of all crimes other than strict liability crimes. ${ }^{10}$ The state must prove these definitional elements beyond a reasonable doubt. Mens rea in this sense is absent, and the defendant must be acquitted of a crime requiring such a mens rea, if the defendant is able to cast a reasonable doubt on whether the mental state was formed in fact.

"Mens rea" is also sometimes used more broadly to refer generally to criminal liability, responsibility, blameworthiness, or culpability. In these senses, it refers to the situation in which the prosecution is able to prove all the definitional elements beyond a reasonable doubt and the defendant fails to establish an affirmative defense. ${ }^{1}$ Under these conditions, the defendant is ultimately blameworthy or criminally responsible. The defendant can avoid mens rea in this broader sense, defeating any criminal blameworthiness, either by negating any element of the crime charged or by establishing an affirmative defense. In the remainder of this Article, we will use the term mens rea in the narrower sense-the specific mental state element required by the definition of the crime.

Defining crimes is a quintessential right of states, ${ }^{12}$ but many crimes have significant common law, and indeed pre-common law, ${ }^{13}$ roots predating the settlements in the Constitution. This raises the central constitutional question about crime: are there constitutional limitations on a state's right to define crimes grounded in common law principles codified

defense be proven by a preponderance of the evidence or by the "intermediate" clear and convincing evidence standard. See, e.g., 18 U.S.C. $\$ 17$ (2000) (placing the burden of proof on defendants in federal trials to prove legal insanity by clear and convincing evidence).

${ }^{10}$ In their influential casebook, Sanford Kadish, Stephen Schulhofer, and Carol Steiker refer to this usage as mens rea in its "narrow" sense. SANFORD H. KADISH, STEPHEN J. Schulhofer \& Carol Steiker, Criminal law and Its Processes: Cases and Materials 213-14 (8th ed. 2007).

"Kadish, Schulhofer, and Steiker refer to this usage as mens rea in the "broader" sense. $I d$. at 213-14. We use the admittedly vague locution "establish an affirmative defense," recognizing that the burden of persuasion may be placed on either the prosecution or the defense.

${ }^{12}$ See Martin v. Ohio, 480 U.S. 228, 232 (1987); Patterson v. New York, 432 U.S. 197, 201-02 (1977). Indeed, there was little substantive federal criminal law until the early 1900s. See Frank O. Bowman III, Fear of Law: Thoughts on Fear of Judging and the State of the Federal Sentencing Guidelines, 44 ST. LouIS U. L.J. 299, 313-14 (2000).

${ }^{13}$ See infra text accompanying notes 305-10 for a discussion of the biological roots of the criminal law in general and of notions of blameworthiness in particular. 
in the Constitution, either expressly or, more fruitfully, implicitly in the doctrine of substantive due process? ${ }^{14}$

In Robinson v. California, ${ }^{15}$ the Court held that the Eighth Amendment prohibited punishing a person for being an addict. The Justices disagreed substantially about the rationale for the holding, and there was no single opinion for the Court. The plurality opinion was replete, however, with suggestions that criminalizing and punishing the status of being an addict is unconstitutional because that status is beyond the control of the addict. ${ }^{16}$ The Robinson Court did not explain how the taking of illegal drugs by an addict-which it took great pains to admit could be criminalized by the state-is any more within the addict's control than the status of being an addict.

Six years later, the Court stepped back from the precipice of constitutionalizing "loss of control" in Powell v. Texas, ${ }^{17}$ which held that the Constitution does not prevent a state from criminalizing public drunkenness, even when the target of the prosecution is suffering from the "disease" of chronic alcoholism and is thus allegedly powerless to control his behavior. Although Justice Marshall's plurality opinion in Powell has been read narrowly as simply an unwillingness to extend Robinson from the impermissibility of punishing a status to the impermissibility of punishing allegedly uncontrollable acts, the opinion signaled more broadly that the Court considered the doctrines of criminal responsibility firmly within the discretion of the states. It said it was loathe "under the aegis of the Cruel and Unusual Punishment Clause" to become "the ultimate arbiter of the standards of criminal responsibility."

14 This presupposes another constitutional question, one that is beyond the scope of this article: whether the whole idea of "substantive due process" is legitimate. Compare Mays v. City of East St. Louis, 123 F.3d 999, 1001 (7th Cir. 1997) (Easterbrook, J.) ("[S]ubstantive due process is an oxymoron."), ROBERT H. BORK, THE TEMPTING OF AMERICA: THE POLITICAL SEDUCTION OF THE LAW 240 (1990) (arguing there is little textual or historical support for the idea of substantive due process), and John Harrison, Substantive Due Process and the Constitutional Text, 83 VA. L. REV. 493, 495 (1997) (same), with Toni M. Massaro, Reviving Hugo Black? The Court's "Jot" for "Jot" Account of Substantive Due Process, 73 N.Y.U. L. REV. 1086, 1091-92 (1998) (arguing that the Court should read the notion of substantive due process even more broadly), and Peter J. Rubin, Square Pegs and Round Holes: Substantive Due Process, Procedural Due Process, and the Bill of Rights, 103 Colum. L. REV. 833, 892 (2003) (same).

15370 U.S. 660 (1962).

${ }^{16}$ As Justice Stewart put it, drug addiction "is an illness which may be contracted innocently or involuntarily," and that imprisonment for such a status inflicts cruel and unusual punishment as surely as if the defendant were being imprisoned "for the 'crime' of having a common cold." Id. at 667.

17392 U.S. 514, 534-37 (1968).

${ }^{18}$ Id. at 537-55 (Black \& Harlan, JJ, concurring). 
We cannot cast aside the centuries-long evolution of the collection of interlocking and overlapping concepts which the common law has utilized to assess the moral accountability of an individual for his antisocial deeds. The doctrines of actus reus, mens rea, insanity, mistake, justification, and duress have historically provided the tools for a constantly shifting adjustment of the tension between the evolving aims of the criminal law and changing religious, moral, philosophical, and medical views of the nature of man. This process of adjustment has always been thought to be the province of the States. ${ }^{19}$

It is difficult to imagine a clearer, more straightforward expression of deference to the states concerning the definitions of crimes and defenses. Yet, beginning in 1975, the Court decided a series of cases that vacillated on the question of the constitutional limits on a state's freedom to define crimes and defenses and the concomitant power to allocate criminal burdens of proof.

In Mullaney v. Wilbur, ${ }^{20}$ the Court considered the constitutionality of Maine's rather unique burden-shifting murder statute. Maine included "malice" as one of the elements of murder, but defined it to exclude killings committed in the heat of passion upon sudden provocation. ${ }^{21}$ Even though malice so defined was an element of the crime-an element the prosecution had to prove beyond a reasonable doubt-the Maine statute imposed the burden of proving provocation/passion on the defendant. ${ }^{22}$ This shifting of the burden of proof clearly violated Winship's requirement that the state must prove every element of the crime charged beyond a reasonable doubt, and the Court had little trouble striking down the statute on that basis. The opinion also contained stunning language, however, that seemed to suggest that Winship applied to any fact bearing on the defendant's "degree of criminal culpability," 23 whether or not it was among the elements of the crime. $^{24}$ It appeared that the Supreme Court was taking a tentative further step toward constitutionalizing substantive criminal law.

The imagined turn toward a more intrusive federal role in the substantive criminal law proved just that-imagined. Two years after the controversial dictum in Mullaney, the Court returned to Powell's more

${ }^{19}$ Id. at 535-36.

${ }^{20} 421$ U.S. 684 (1975).

${ }^{21} \mathrm{Id}$. at 688 .

22 Id.

${ }^{23}$ Id. at 698 .

${ }^{24}$ This definitional tension between elemental facts and non-elemental facts should have a familiar ring. That same distinction has been the object of the Court's recent and controversial attention in the context of the Sixth Amendment in the so-called Apprendi line of cases, culminating in the Court's striking down of the federal sentencing guidelines in United States v. Booker, 543 U.S. 220 (2005). 
restrained approach in Patterson v. New York, ${ }^{25}$ which addressed a New York statute that was functionally equivalent to the Maine statute considered in Mullaney. To reduce a killing from murder to manslaughter, New York had adopted the Model Penal Code's "extreme emotional disturbance" test. ${ }^{26}$ This doctrine was meant to serve the same partially mitigating function as the provocation/passion formula, but it provided a broader test that was allegedly more consistent with modern understanding of behavior and that better tracked culpability. Unlike Maine, however, New York explicitly treated this doctrine as a partial affirmative defense and placed the burden of persuasion on the defendant.

Although "extreme emotional disturbance" is as relevant to the degree of a defendant's culpability as "heat of passion," the Court rejected a broad reading of Mullaney that would have required the state to prove beyond a reasonable doubt every fact bearing on culpability, and instead gave determinative weight to New York's decision to treat emotional disturbance as a partial affirmative defense:

[E]ven if we were to hold that a State must prove sanity to convict once that fact is put in issue [a position the Court rejected], it would not necessarily follow that a State must prove beyond a reasonable doubt every fact, the existence or nonexistence of which it is willing to recognize as an exculpatory or mitigating circumstance affecting the degree of culpability or the severity of the punishment. ${ }^{27}$

The Court strongly reiterated that states have extensive discretion to define crimes and defenses as they wish and to allocate the burden of persuasion accordingly:

If the State . . chooses to recognize a factor that mitigates the degree of criminality or punishment, we think the State may assure itself that the fact has been established with reasonable certainty. To recognize at all a mitigating circumstance does not require the State to prove its nonexistence in each case in which the fact is put in issue, if in its judgment this would be too cumbersome, too expensive, and too inaccurate. ${ }^{28}$

The Patterson Court did recognize that there were constitutional limits to the state's ability to redefine at least some elements as affirmative defenses and thus to shift the burden of persuasion, but the examples it gave-such as a legislature declaring a person presumptively guilty of a

\footnotetext{
25432 U.S. 197 (1977).

${ }^{26}$ Model Penal Code $\S 210.3(1)$ (a)-(b) (1962).

${ }^{27}$ Patterson, 432 U.S. at 207.

${ }^{28}$ Id. at 209.
} 
crime $^{29}$ - seemed to place little, if any, effective limit on the state's discretion. ${ }^{30}$

Patterson did not explicitly overrule Mullaney, but it seemed inconsistent with it, and that apparent inconsistency created an industry of commentary. ${ }^{31}$ Indeed, the two cases together spawned an enormous debate between the "substantivists" and "proceduralists." 32

Substantivists believed that Mullaney was correctly decided, that Patterson threatened to erode Winship's protections, and that states could not, by the mere artifice of re-labeling an element as an affirmative defense, relieve the state of its burden of proof on the definitional elements. ${ }^{33}$ For example, imagine a homicide statute that defined "intentional action that caused the death of a human being" as first degree murder and then forced the defendant to prove as affirmative defenses that the defendant did not intend to cause death (reducing the grade to second degree murder), was not aware of a substantial and unjustifiable risk of death (reducing the grade to manslaughter), and should not have been aware of a substantial and unjustifiable risk of death (acquittal). ${ }^{34}$ In such a situation, Winship's protection of liberty would be largely illusory.

In contrast, the proceduralists thought that, as a matter of constitutional law if not of policy, the states have virtually limitless discretion to re-label traditional elemental facts as affirmative defenses. ${ }^{35}$ Indeed, that very decision - whether a fact should be an element for which the state has the burden of proof or an affirmative defense that the defendant might be

${ }^{29}$ Id. at 210.

${ }^{30}$ See Westen, supra note 6 , at 161 (claiming that because the distribution of elements and defenses is entirely malleable, depending on how states define crimes and defenses, the constitutional rules concerning burden of persuasion are themselves malleable).

${ }^{3}$ See, e.g., Ronald J. Allen, Structuring Jury Decisionmaking in Criminal Cases: A Unified Constitutional Approach to Evidentiary Devices, 94 HARV. L. REV. 321 (1980).

${ }^{32}$ Larry Alexander describes the debate. Larry Alexander, The Supreme Court, Dr. Jekyll, and the Due Process of Proof, 1996 SuP. CT. REv. 191, 193-96.

33 See id.

${ }^{34}$ Such a statute would of course raise constitutional eyebrows after Morissette $v$. United States, 342 U.S. 246 (1952), in which the Court expressed distaste for strict liability applied to core, common law offenses. Nonetheless, Morissette was not constitutionally-based and it is still an open question whether a legislature can choose to make any crime a strict liability crime as long as it makes clear that it intends to do so for good reason. One of us (Hoffman) has discussed an even more extreme case of re-labeling elements as non-elements, albeit in the context of Apprendi v. New Jersey, 530 U.S. 466 (2000) (holding that the state must charge and prove beyond a reasonable doubt any fact other than prior criminal record that will have the effect of increasing the penalty for a crime beyond the statutory maximum): Could a state define all crimes as having a single element (intending to harm another person) and then change all other elements to sentencing factors? Morris B. Hoffman, The Case for Jury Sentencing, 52 DuKE L.J. 951, 984 n.127 (2003).

35 See Alexander, supra note 32. 
required to prove-is precisely the kind of policy decision the proceduralists believed cases like Powell and Patterson properly placed within the state's judgment.

In Montana v. Egelhoff, ${ }^{36}$ which was the last important general mens rea case decided before Clark, the Court addressed these issues, but in a context different from re-labeling elements as affirmative defenses. The question answered by Egelhoff was whether, and under what conditions, the State may constitutionally bar a defendant from introducing relevant and reliable evidence for the purpose of negating an element. ${ }^{37}$ Egelhoff was charged with first degree murder under a Montana homicide statute that defined the crime as requiring purpose or knowledge. ${ }^{38}$ Egelhoff sought to negate the inference of intent arising from strong physical evidence consistent with the formation of an intent to kill by introducing evidence of his incontrovertibly extreme intoxication at the time of the crime. ${ }^{39}$ The intoxication evidence was his only plausible means to negate intent, but the evidence of intoxication was excluded from the jury under a Montana statute that specifically barred the use of evidence of voluntary intoxication to negate mens rea. ${ }^{40}$

The Supreme Court held that such exclusion did not violate the defendant's due process rights. ${ }^{41}$ The Justices disagreed about whether the Montana statute was an evidentiary rule or a redefinition of the offense of murder. ${ }^{42}$ All nine Justices agreed, however, that states had substantial discretion to define crimes. As Justice Ginsburg said in her concurrence, citing Powell, "States enjoy wide latitude in defining the elements of criminal offenses, particularly when determining 'the extent to which moral

${ }^{36} 518$ U.S. 37 (1996)

${ }^{37} \mathrm{Id}$.

${ }^{38}$ Id. at $40-41$.

${ }^{39}$ Id. at 41 .

${ }^{40}$ Mont. Code ANN. § 45-2-203 (1995).

${ }^{41}$ Egelhoff, 518 U.S. at 56.

42 Justice Scalia's plurality opinion, joined by Chief Justice Rehnquist and Justices Kennedy and Thomas, endorsed concurring Justice Ginsburg's view that Montana's statute "embodies a legislative judgment regarding the circumstances under which individuals may be held criminally responsible for their actions," but Justice Scalia nonetheless analyzed the statute as an evidentiary rule because that was how the Supreme Court of Montana chose to analyze it. Id. at 50 n.4. In dissent, Justice O'Connor argued that Montana's statute was a rule of evidence. Id. at 71-73. Justice Souter accepted Montana's own interpretation of the statute as a rule of evidence, but suggested that the statute had implicitly redefined the elements of the crime. Id. at 73. Justices Breyer and Stevens also joined Justice O'Connor in considering themselves bound by the Montana Supreme Court's interpretation, but argued that the statute created anomalies and made guilt turn upon irrelevant external circumstances rather than the defendant's state of mind. Id. at 79. 
culpability should be a prerequisite to conviction of a crime.",43 Moreover, all nine Justices agreed that a criminal defendant does not have an absolute right to present evidence relevant to his defense.

Justice Scalia began the plurality opinion by noting that there was no indication in historical practice that the use of voluntary intoxication evidence to negate mens rea was so entrenched that it was a "fundamental principle of justice." ${ }^{44} \mathrm{He}$ continued by arguing that the defendant's right to introduce even "crucial" and reliable evidence was not absolute and could yield to "valid state justifications" that might support exclusion. ${ }^{45}$ One might of course take issue with some or all of these justifications, but these kinds of policy decisions are precisely the kinds of decisions arguably left to state legislatures. ${ }^{46}$

The plurality also made short work of Egelhoff's argument that the Montana rule violated Winship. Justice Scalia reasoned that Montana's rule did not shift the burden of persuasion, but by excluding intoxication evidence simply made it easier for Montana to prove mens rea beyond a

${ }^{43}$ Id. at 58 (citing Powell v. Texas, 392 U.S. 514, 545 (1968)) (Black, J., concurring).

${ }^{44}$ An argument could be made that the older authorities, such as Hale, Blackstone, and Story, failed adequately to distinguish between the two senses of mens rea described in supra notes 10-11, and that they were referring to the broader sense in rejecting an intoxication defense. Nonetheless, Justice Scalia was correct about the practice in the states. At most, there was a trend in favor of introducing such evidence, albeit almost always with limitations. Egelhoff, 518 U.S. at 37.

${ }^{45}$ Justice Scalia posited several such justifications. First, a state might wish to deter intoxication itself by holding drunken defendants strictly liable for all consequences that occur, even if they lacked mens rea for the aggravated results. Second, the rule operates as a specific deterrent by imprisoning people who cannot control their violent conduct while intoxicated. Third, the rule reflects society's moral perception that a defendant who voluntarily impaired his own faculties should be held strictly accountable for the consequences. Finally, intoxication evidence may be misleading because there is evidence that culture rather than pharmacology largely explains the connection between crime and intoxication. Jurors who have been led to believe the opposite will be too quick to conclude that intoxicated defendants were "biologically incapable" of forming mens rea. Id. at 41-51.

${ }^{46}$ Justice O'Connor's dissent focused on the "'fundamental principle' that a defendant has ... a fair opportunity to put forward his defense." Id. at 71 . She argued that it was fundamentally unfair to prevent the defendant from mounting a full defense with relevant evidence that alone could exonerate him, without close examination of competing state interests, an examination she found wanting. Id at 72-73. For example, Montana allowed evidence of involuntary intoxication to be used to negate mens rea, a rule arguably inconsistent with the claim that intoxication evidence misleads jurors about the formation of mens rea. The dissent also noted that Justice Scalia's policy reasons were not articulated by Montana, either in legislative history or even in the briefs. Id. at 66-67. Montana had instead argued that the "sole purpose" for disallowance was "to keep from the jury's consideration a category of evidence that helps the defendant's case and weakens the government's case." Id. at 68 . 
reasonable doubt, an effect that any evidentiary rule might produce. ${ }^{47}$ Such burden-reducing evidentiary rules are constitutionally permissible unless they themselves violate a fundamental principle of fairness, which, Justice Scalia had already concluded, Montana's rule did not. ${ }^{48}$

This was the state of the law until the Court had its chance to speak again in Clark. Before we address that opinion, we first briefly consider the concept of mental disorder, and then review in some depth well-settled principles of criminal responsibility and the relevance of mental disorder to those principles.

\section{MENTAL DISORDER AND CRIMINAL RESPONSIBILITY}

What is a "mental disorder" and what is its potential relevance to whether a person suffering from it acted, possessed a requisite mens rea, or qualified for a mitigating or excusing condition such as legal insanity? ${ }^{49}$ To answer these questions requires more detail about the nature of recognized mental disorders and the law's criteria for act, mens rea, and legal insanity.

\section{A. MENTAL DISORDER}

There is no consensus-philosophically or scientifically-on the definition of "mental disorder." That lack of consensus should hardly surprise us. "Disorder" and "order," abnormality and normality, are normative terms applied to behavior that science cannot independently define and that therefore inevitably lead to disagreement. They implicate many difficult empirical and theoretical questions that are relevant to our argument, but are largely beyond its scope. We will later have occasion to examine some of these questions, but for now let us focus on the current scientific and clinical orthodoxy about mental disorder.

Probably the most widely used definition in the United States, and perhaps in the world, is contained in the American Psychiatric Association's Diagnostic and Statistical Manual of Mental Disorders. ${ }^{50}$ This document admits, however, that "no definition adequately specifies precise boundaries for the concept of "mental disorder,",51 and that its

${ }^{47}$ Id. at 55 (plurality opinion).

48 Id. at 41-51.

${ }^{49}$ For purposes of this Article, we limit discussion of excuses to legal insanity, but mental disorder might also be relevant to other excuses depending on how the other excuse doctrines are interpreted.

${ }^{50}$ am. Psychiatric ass'n, Diagnostic and Statistical Manual of Mental DISORDERS, 4TH EDITION-TEXT REVISION xxx-xxxi (4th ed. 2000) [hereinafter DSM-IV-TR] (providing a definition).

${ }^{51}$ Id. at $\mathrm{xxx}$. 
definition has been subjected to substantial criticism. ${ }^{52}$ The Supreme Court has repeatedly and opportunistically used this disagreement to justify outcomes as disparate as requiring an intermediate, "clear and convincing evidence" burden of proof in involuntary civil commitment cases, ${ }^{53}$ rejecting a constitutionalized control test for criminal responsibility ${ }^{54}$ and upholding the constitutionality of an especially onerous form of involuntary commitment for so-called mentally abnormal, sexually violent predators. ${ }^{55}$ As we shall see in the next Part, they again use this conclusion to support their argument in Clark. $^{56}$

Nevertheless, there is substantial agreement that some behavior, especially behavior indicative primarily of a loss of the capacity for rationality, should be considered the product of a biological or psychological defect. For example, most observers agree that a gross and substantial loss of touch with reality qualifies as a severe abnormality. Indeed, there are special legal rules for the differential treatment of people with such abnormalities in most areas of civil and criminal law. ${ }^{57}$ Within the latter, for example, in addition to doctrines concerning criminal responsibility, there are doctrines concerning competence to plead guilty, competence to stand trial, competence to be sentenced, and competence to be executed.

There are many open conceptual and empirical questions about mental disorders, but the law routinely deals with cases involving people who suffer from them. One way to think about the difficult questions about mental state and blameworthiness is to analogize them to electricity.

52 See, e.g., Jerome C. Wakefield, Disorder as Harmful Dysfunction: A Conceptual Critique of DSM-III-R's Definition of Mental Disorder, 99 PSYCH. REv. 232 (1993) (offering critique of same definition used in DSM-IV-TR). See generally PETER CONRAD, The Medicalization of Society: On the Transformation of Human Conditions into TREATABLE DisORDERS 46-69 (2007) (using ADHD as an example of the easy expansion and fluidity of psychiatric diagnoses); ALLAN V. HORWITZ \& JEROME C. WAKEFIELD, THE LOSS

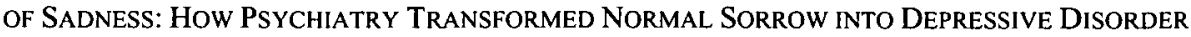
(2007) (offering an extensive conceptual and empirical analysis and critique of current diagnostic criteria and practice using the diagnosis of depression as a case study and offering an evolutionary approach to ameliorate existing definitional problems). In his introduction to the Horwitz and Wakefield book, the primary author of the current DSM approach, Dr. Robert L. Spitzer, concedes that the book's critique has caused him to rethink his own position. ROBERT L. SPITZER, Foreward to HORWITZ \& WAKEFIELD, supra, at viii-ix (terming the argument concerning depression "devastating").

${ }^{53}$ Addington v. Texas, 441 U.S. 418, 432-33 (1979).

${ }^{54}$ Powell v. Texas, 392 U.S. 514, 535-36(1968).

${ }^{55}$ Kansas v. Hendricks, 521 U.S. 346, 359 (1997).

${ }^{56}$ See infra text accompanying notes 162-65.

${ }^{57}$ See Stephen J. Morse, Crazy Reasons, 10 J. ContemP. Legal Issues 189, 193 (1999) [hereinafter Morse, Crazy Reasons]. 
Modern physics has exposed the foundations of the elemental particles, including the electron, as a kind of mysterious expression of a set of strange and counter-intuitive physical rules; in some ways it seems the more we learn about quantum physics the more our macro-reality seems to be an illusion. Yet those foundational uncertainties hardly disable us from using electricity, or designing circuits.

Healthy skepticism about mental disorder and the potential relation between it and criminal responsibility, especially in marginal cases, is warranted; outright rejection is not.

\section{B. THE ACT DOCTRINE}

An intentional act is crucial to the definition of any conduct we wish to criminalize. Indeed, our very use of the word "conduct" in the last sentence conveys the notion that acts, not mere thoughts or desires, are the domain of crime. Although thoughts and desires can be intentionally produced, and can be evaluated morally, ${ }^{58}$ we do not criminalize these mental states because by themselves they do no harm, and the reach of the criminal law is defined in large measure by the harm principle. $^{59}$ Moreover, the requirement of an act before blame and punishment may be imposed appears to have constitutional status. ${ }^{60}$ On the other hand, harms or threatened harms, all of which result from actual or potential body movements or intentional lack of movement, cannot be attributed to the agent as an agent unless those movements or lack of motion are intentional. Spasms and reflexes, for example, can cause or risk harm, but in most cases we do not hold the agent responsible for them. The challenge for the law is how to define a "voluntary" or "intentional" act (or omission in cases in which the agent has a duty to act) in a sensible and useful way.

The criminal law's evolving answer has never been entirely satisfactory. Indeed, some have resorted to defining a criminally cognizable "act" by what it is not. ${ }^{61}$ Nonetheless, as with the notion of "mental state," the law has managed to develop a useful working definition: an "act" for purposes of the criminal law is an intentional bodily movement (or intentional inaction) performed in a state of reasonably integrated

\footnotetext{
${ }^{58}$ Merely coveting one's neighbor's wife, for example, violates the Tenth Commandment. Exodus 20:17; Deuteronomy 5:21.

59 Joel Feinberg, Harm to Others: The Moral Limits of the Criminal LaW 1-64 (1984).

${ }^{60}$ Robinson v. California, 370 U.S. 660 (1962).

${ }^{61}$ See, e.g., MOdel Penal CODE $\S 2.01(2)$ (1962) (defining reflexes and sleepwalking, inter alia, as not actions).
} 
consciousness. $^{62}$ "Intentional" in this definition means that the agent's bodily movement is at least potentially rationalizable as having been performed for a reason.

Mental disorder seldom interferes with an agent's ability to act intentionally, even though in infrequent cases it may cloud consciousness. For example, depersonalization and less severe delirium can compromise consciousness without rendering the person's movements non-actions. ${ }^{63} \mathrm{It}$ is only at the extreme, when consciousness is substantially or completely obliterated, that the law will acquit the defendant because action was lacking. Sleepwalking is a classic example. ${ }^{64}$ There is a debate about whether apparently environmentally responsive, goal-directed behavior performed with clouded consciousness should be considered action or not, ${ }^{65}$ but criminal behavior performed in such states either negates the action requirement of the prima facie case or it satisfies the criteria for the affirmative defense of automatism. ${ }^{66}$ Sufficiently clouded consciousness as a result of mental disorder might thus defeat criminal responsibility, but, again, these cases are rare.

\section{MENS REA}

As Justice Holmes famously observed, "Even a dog distinguishes between being stumbled over and being kicked."67 Mens rea is considered the royal road to the assessment of culpability because it indicates the agent's attitude towards the rights and interests of his fellow citizens when

\footnotetext{
${ }^{62}$ Alas, sufficiently integrated consciousness is also typically described by negative criteria. See, e.g., MODEL PENAL CODE § 2.01(1) (e.g., sleepwalking is not action).

${ }^{63}$ DSM-IV-TR, supra note 50, at 135-41 (explaining that the point prevalence for delirium is marked by a disturbance of consciousness; point prevalence for in adults under the age of 55 is $.4 \%$ ); id. at $530-32$ (Depersonalization Disorder is marked by episodes of detachment or estrangement from one's self or feelings of being an automaton). Many other disorders can also cause consciousness clouding although such clouding is not a crucial diagnostic criterion.

${ }^{64}$ Id. at 639-44 (describing sleepwalking disorder); see also Fain v. Commonwealth, 39 Am. Rep. 213 (Ky. App. Ct. 1879).

${ }^{65}$ See, e.g., MiChaEl S. MOORE, ACT AND CRIME 49-52, 135-55, 257-58 (1993) (arguing that cases of compromised consciousness should be treated as non-action); Michael S. Moore, More on Act and Crime, 142 U. PA. L. Rev. 1749, 1804-20 (1994) (same); Stephen J. Morse, Culpability and Control, 142 U. PA. L. REv. 1587, 1641-52 (1994) (arguing that clouded consciousness should be treated as an affirmative defense). See generally Bernard Williams, The Actus Reus of Dr. Caligari, 142 U. PA. L. REv. 1661 (1994) (asserting that clouded consciousness should be treated as action).

66 WAYNe R. LAFAVE, CRIMINAL LAW 466-71 (4th ed. 2003).

${ }^{67}$ Oliver Wendell Holmes, Jr., The Common LaW 3 (Dover ed., Dover Publ'ns, Inc. 1991) (1881).
} 
an agent harms or threatens them. As Justice Jackson wrote in Morissette $v$. United States,

The contention that an injury can amount to a crime only when inflicted by intention is no provincial or transient notion. It is as universal and persistent in mature systems of law as belief in freedom of the human will and a consequent ability and duty of the normal individual to choose between good and evil. A relation between some mental element and punishment for a harmful act is almost as instinctive as the child's familiar exculpatory "But I didn't mean to" ....

Intentional body movements may cause harms, but if the defendant has been acting as carefully as we can expect a morally well-constituted agent to act under the circumstances, we conclude that the agent has done nothing wrong, civilly or criminally. His behavior has shown all the respect for the rights of others that we demand. Accidents happen that are no one's fault. Similarly, an agent who harms another on purpose is more blameworthy and deserves more punishment than an agent who causes precisely the same harm, but does so unaware that his unreasonable conduct was placing the victim at substantial risk of incurring that harm. The disregard of the former for the rights of his victims is total; the disregard of the latter is serious, but less so. Mens rea is crucial to defining fault and justifying punishment.

Over the centuries, the criminal law has developed a very large number of mens rea terms to mark such differences in culpability. Modern codes have attempted to streamline the mens rea vocabulary. The Model Penal Code, for example, has consolidated mens rea to four terms. ${ }^{69}$ Nevertheless, the common law process of interpretation continues as courts struggle to find more accurate methods to evaluate blameworthiness.

With rare exception, mens rea terms, such as intent or knowledge, have their ordinary, non-technical meanings. For example, intent does not require any level of commitment to the agent's goal or any degree of moral evaluation. ${ }^{70}$ Intent simply means that the agent did something on purpose.

${ }^{68} 342$ U.S. 246, 250-51 (1952) (footnote omitted).

${ }^{69}$ Those four levels of culpability, in order of decreasing blameworthiness, are: purpose, knowledge, recklessness, and negligence. Model Penal CODE \& COMMENTARIES, PART I $\S 2.02(2)$ (1985). Several scholars have argued that these apparently distinct levels of culpability are in fact indistinguishable from one another, at least at their margins. See, e.g., Larry Alexander, Insufficient Concern: A Unified Conception of Criminal Culpability, 88 CAL. L. ReV. 931 (2000); Kimberley K. Ferzan, Opaque Recklessness, 91 J. CRIM. L. \& CRIMINology 597 (2001); Douglas N. Hasak \& Craig A. Callender, Willful Ignorance, Knowledge, and the "Equal Culpability" Thesis: A Study of the Deeper Significance of the Principle of Legality, 1994 WIS. L. REV. 29 (1994); Morris B. Hoffman, Booker, Pragmatism, and the Moral Jury, 13 GeO. MASON L. REv. 455, 473-74 (2005).

${ }^{7}$ See KADISH ET AL., supra note 10 , at 213 . There are some exceptions. Premeditation, which is used in some jurisdictions as a criterion for the most serious form of intentional 
Even where a mens rea term is legal jargon, such as "recklessness," its criteria-conscious awareness of a substantial and unjustifiable risk-have traditional meanings. To determine if mental disorder negates mens rea, one must simply ask, using straightforward common sense to provide an answer, if the defendant's disordered mental state actually indicates that mens rea was not formed on the occasion.

Doctrines that permit defendants to present mental disorder evidence to negate mens rea are often misleadingly termed "diminished capacity," suggesting that these doctrines are some kind of mitigation or partial excuse. This is incorrect. They refer to a straightforward denial of a requisite element, akin to a denial that one acted or to a mistake of fact. ${ }^{71}$ They are not a lesser form of the insanity defense. The failure to recognize this clear distinction often produces faulty reasoning about whether a defendant should be permitted to introduce mental disorder evidence to negate mens rea because courts wrongly believe the defendant is requesting the court to create a "mini" insanity defense. ${ }^{72}$

Mental disorders relevant to mens rea most frequently produce disordered cognition, such as hallucinations or delusions, or untoward, sometimes strong, desires, such as the desire to have sexual relations with minors or the desire to set fires or to take controlled substances. In other words, mental disorder produces crazy desires or crazy beliefs about reality, but it virtually never prevents a defendant from meeting the law's criteria for intention, knowledge, conscious awareness, and other mens rea terms. ${ }^{73}$

Likewise, mental disorder seldom disables a defendant from having the capacity to form a mens rea. ${ }^{74}$ Modern inquiries into state of mind, both academic and judicial, seem obsessed with the vexed question of whether a defendant had the capacity to form mens rea, but either a defendant had the requisite mens rea or he did not. Mental disorder may in some cases demonstrate that the defendant did not form the mens rea at the time of the crime. Not having a mens rea or having a mental state inconsistent with the requisite mens rea does not mean, however, that someone was incapable of

murder, under some interpretations may include the requirement of a particularly rational or even morally evaluative process of preconsideration before committing intentional homicide. Negligence standards employing a "reasonableness" test of course require normative judgment about whether behavior is reasonable.

${ }^{71}$ Stephen J. Morse, Undiminished Confusion in Diminished Capacity, 75 J. CrIM. L. \& Criminology 1, 6(1984).

72 See, e.g., Bethea v. United States, 365 A.2d 64 (D.C. 1976). The Arizona case the Supreme Court considers in Clark makes precisely this error. State v. Mott, 931 P.2d 1046, 1050-51 (Ariz. 1997). Indeed, as we shall see, the Clark majority itself blurs the two doctrines. See infra Part IV.B.

${ }^{73}$ See Morse, Crazy Reasons, supra note 57, at 197-98.

${ }^{74}$ Morse, supra note 71, at 42. 
forming it. If an agent lacks the capacity to do something, it follows that the agent did not do it in fact. Thus, evidence about the defendant's capacity to form a mens rea is logically and factually relevant to whether it was actually formed.

Asking about a defendant's capacity to form a mental state never provides better information than inquiring directly whether the mens rea was formed in fact, which is the ultimate legal question. Resolving questions about capacity requires a counterfactual inquiry that we lack the clinical and scientific resources to answer. When an expert testifies that a defendant lacked the capacity to form a mens rea, that opinion seldom has a clinical or scientific basis. It was precisely these types of difficulties that led California to bar testimony about the defendant's capacity to form a mens rea, although it did permit testimony about whether the mental state was formed in fact. $^{75}$

Consider the Model Penal Code's example of a hallucinating killer who strangles a victim believing that he is squeezing a lemon. ${ }^{76}$ Believing that you are squeezing a lemon is flatly inconsistent with believing that you are squeezing someone's throat for the purpose of killing the victim. What does it mean to ask whether such a person had the capacity to form the intent to kill? How do we interpret this question?

One possibility is that we are asking whether the person could have formed an intent to kill if he believed that he was squeezing a person's throat - whether, that is, he had the general capacity to form an intent to kill a person. This requires a speculative answer, but the answer is probably "yes," because most people have the general capacity to form all species of intents, including an intent to kill.

The second possible interpretation is that we are asking whether at the precise moment that a person believes he is squeezing a lemon, he is also capable of forming an intent to kill the object he is squeezing. The answer to this second question is "no," because one cannot at precisely the same moment form two different and inconsistent mental states. This is tautologically and trivially true. But this interpretation shows that we are not really considering the defendant's capacities at all. The reason we know that he "lacked the capacity" to form the intent to kill at that precise moment is because he in fact formed another mental state. Our knowledge of this temporally specific form of "incapacity" is doing no explanatory

${ }^{75}$ Cal. Penal Code $\S 28$ (1998).

${ }^{76}$ Model Penal Code AND Commentaries $\S 4.01$ at 166 (1985). This example is silly because mental disorder does not work this way; it does not produce such beliefs. Nevertheless, the virtue of the example is that it is clear. 
work. We conclude that incapacity existed because we know ex post that another mental state was in fact formed.

So far, the discussion of capacity has assumed that we incontrovertibly know what mental state the defendant in fact formed. In the real world of criminal law, however, mental state must be proved by the prosecution, and is often countered by defense evidence. To continue the lemon example, imagine that there was good evidence to suggest that the defendant sporadically hallucinated that non-lemons were in fact lemons, but it is not clear whether he was suffering from that hallucination when he strangled his victim. He claims that he was, but there was also evidence of bad blood between him and the victim. ${ }^{77}$ Perhaps he is lying, or he is so distraught about committing homicide that he has unwittingly and incorrectly convinced himself that he was hallucinating.

We can confidently conclude that he probably lacked the capacity to believe that the victim was not the small yellow citrus fruit only if we are equally confident that he almost always hallucinates that people are lemons. Again, our conclusion about capacity would be based on what mental states had been formed in fact rather than based on our direct and independent evidence about the person's capacities. The mental states of people with mental disorder, like those of people without disorder, are often variable, however, and speculation about capacity on a particular occasion will be of little help.

For all of these reasons, evidence of mental disorder allegedly relevant to a person's capacity to form a mental state will almost never help resolve whether that state was formed in fact.

The examples of Daniel M'Naghten and Andrea Yates will help demonstrate that even the most delusional or hallucinating person can form the requisite mental state. M'Naghten delusionally believed that there was a conspiratorial Tory plot to kill him, and formed a preemptive plan to kill the Tory Prime Minister, Robert Peel. ${ }^{78}$ When he shot and killed Peel's secretary, Drummond, believing the secretary was Peel, he surely intended to kill a person. ${ }^{79}$ Likewise, Andrea Yates believed that unless she killed her children, they would become corrupt and would be tormented by Satan

77 This was almost precisely the situation in Clark. There was no doubt Clark was suffering from paranoid schizophrenia, but there was considerable doubt about whether his delusions really interfered with his ability to intend to kill a policeman. Just days prior to the incident, he had bragged to his friends about wanting to kill policemen. See infra text accompanying notes 111-20.

78 Richard Moran, KNOWing Right from Wrong: The INSANITy DEFENSE OF DANiel MCNAUGHTAN 10 (1981).

${ }^{79}$ M'Naghten's Case, (1843) 8 Eng. Rep. 718 (H.L.). 
for eternity. ${ }^{80}$ She therefore decided to kill her children. ${ }^{81}$ She knew they were human beings and that human beings are killed by drowning. Ms. Yates surely intended to kill the five children when she drowned them in the bathtub. Likewise, a person suffering from auditory hallucinations who hears God's voice command him to kill surely forms the intention to k:ll when he kills in response to the hallucinated command.

Admittedly, on rare occasions, psychotic mentation is genuinely inconsistent with the formation of mens rea. In a well-known California case ${ }^{82}$ the defendant, Wetmore, was caught in the victim's apartment under conditions suggesting that he intended to steal the victim's property. Charged with burglary, the defendant claimed that he delusionally believed that the apartment and the property belonged to him. ${ }^{83}$ If he told the truth, he did not intend to enter the apartment of another or to commit the felony of larceny, the elements of which include intentionally taking and carrying away the property of another.

Note that even if mental disorder does negate subjective mental states such as purpose, intention, knowledge, or conscious awareness of risk, it would never negate the objective negligence standard. The person with mental disorder who is unaware of a risk that a reasonable person should be aware of is by definition unreasonable. Even the Model Penal Code, which individualizes the negligence inquiry somewhat by requiring the decision maker to consider the behavior of a "reasonable person ... in the actor's situation" before making a finding of negligence,${ }^{84}$ would not go so far as to consider mental disorder-irrational behavior-as part of the "situation." The Model Penal Code never gives a clear definition of the "situation," but it does make clear that it wishes to avoid complete subjectivization of the reasonable person standard. ${ }^{85}$ To assess reasonableness from the standpoint of the "reasonable irrational" person would deprive the negligence standard of all objectivity. ${ }^{86}$ Consider the lemon example again. The killer is at least

${ }^{80}$ Phillip Resnick, Andrea Yates Case: Insanity on Trial, 55 CLEV. ST. L. REV. 147, 149 (2007); see also Deborah W. Denno, Who Is Andrea Yates? A Short Story About Insanity, 10 DUKE J. Gender L. \& POL'Y 1 (2003) (providing a thorough account of the entire background and an analysis of the expert testimony).

${ }^{81}$ Resnick, supra note 80 ; see also Denno, supra note 80.

${ }^{82}$ People v. Wetmore, 583 P.2d 1308 (Cal. 1978).

${ }^{83}$ Id. at 1310 .

${ }^{84}$ MODEL PENAL CODE $§ 2.02(2)$ (d) (1962) (emphasis added).

${ }^{85}$ MODEl Penal CODE AND COMMENTARIES $\S 2.02$ at 242 (1985).

${ }^{86}$ Failure to recognize this point and the incorrect belief that the Model Penal Code adopts nearly complete subjectivization for negligence are major analytic reasons that the primary contemporary proposal to abolish the insanity defense fails. See Christopher Slobogin, An End to Insanity: Recasting the Role of Mental Disability in Criminal Cases, 86 VA. L. REV. 1199, 1239 (2000), reprinted in expanded form, but with unchanged analysis, in 
guilty of negligent homicide because a reasonable person should have been aware of a substantial and unjustifiable risk that the object being squeezed was a person's throat and not a lemon. We defer discussion of whether a conviction and punishment for negligent homicide in such a case would be fair or even make sense until a later section of the article. ${ }^{87}$

In other cases, mental disorder may not necessarily be inconsistent with formation of mens rea, but evidence of disorder may help bolster the defendant's claim that he did not form it. For example, suppose a psychotically disorganized person gets lost in an empty part of town on a cold winter's night and cannot find his way home. To escape the cold, he breaks into a building, is caught, and is charged with burglary on the theory that he intended to steal. In this case, he is fully capable of forming the intent to steal, but his mental disorder helps explain why he broke in simply to keep warm.

Again, the crucial issue is to determine what the defendant's actual mental state was and to compare that mental state to the mental state required by the crime charged. Of course, the lurking problem is that it is sometimes very difficult to determine a defendant's mental state at the time of the crime. Memories fade or are wittingly or unwittingly shaped by what happens afterwards. Defendants have powerful incentives to lie, but these difficulties arise in all retrospective mental state evaluations, and not just in cases involving mental disorder. As we discuss later in this Article, one of the primary skills we have evolved over the last 100,000 years is the ability to discern the intentions of other humans. ${ }^{88}$ Like Holmes's dog, jurors are quite good at recognizing the difference between a kick and a stumble.

\section{LEGAL INSANITY}

The tests for legal insanity may be placed in two broad categoriescognitive and control (also called "volitional"). There is some doctrinal variation among the jurisdictions, but the essential questions are similar.

Cognitive tests ask whether, at the time of the crime, the defendant was disabled by mental disorder from knowing, appreciating, or understanding the nature of his conduct or that it was morally or legally

Christopher Slobogin, Minding Justice: laws That Deprive People with Mental DisABILITY OF LIFE AND LIBERTY 52-53 (2006) [hereinafter Slobogin, An End to Insanity]; see also Christopher Slobogin, Minding Justice: Laws That Deprive People with MENTAL Disability OF LifE AND LiberTy (2006) [hereinafter SLOBOgin, Minding JustiCE]. Professor Slobogin's "integrationist" alternative to the insanity defense is discussed infra in the text accompanying notes 229-62.

${ }^{87}$ See infra Part V.

${ }^{88}$ See infra text accompanying note $314-31$. 
wrong. ${ }^{89}$ Control tests ask whether, as a result of mental disorder, the defendant was unable at the time of the crime to control his conduct or to conform his conduct to the requirements of the law. ${ }^{90}$

Prior to the 1980s, all American states and all federal circuits had an insanity defense test. The most common was M'Naghten or some variant of its cognitive inquiry. Beginning in the last part of the nineteenth century, a minority of jurisdictions added a control test, but no jurisdiction adopted solely a control test. The Model Penal Code promulgated an influential test that had both a cognitive and a control prong, and that used less all-or-none, bright-line language than standard insanity rules. ${ }^{91}$ By the time John W. Hinckley was acquitted by reason of insanity in 1982 for attempting to assassinate President Reagan and others, most states that had reformed their insanity defense followed the Model Penal Code, as had all but one federal circuit. $^{92}$

Hinckley was acquitted under the Model Penal Code test, which spurred an immense federal and state legislative backlash against the insanity defense in general and control tests in particular. In the wake of the unpopular verdict, many states reverted to a pure cognitive test, and Congress adopted such a test, providing for the first time a uniform test for legal insanity in federal trials. ${ }^{93}$ In addition, Congress and many state legislatures placed the burden of persuasion on the defendant. ${ }^{94}$ Five states abolished the insanity defense altogether, although one state supreme court found abolition unconstitutional. ${ }^{95}$ The Supreme Court has never ruled, however, whether the insanity defense is or is not constitutionally required.

${ }^{89}$ MOdel Penal CODE $\S 4.01(1)$ (1962).

${ }^{90}$ Sometimes the tests for insanity are phrased instead as tests for "sanity," in which case, of course, the disjunctive becomes conjunctive. Thus, the cognitive test for sanity is whether a defendant understands the nature of his actions and knows they are wrong. (These are the two traditional M'Naghten prongs, one of which was dispensed with by Clark. See infra text accompanying notes 121-38.)

${ }^{91}$ Model Penal CODE $\S 4.01$ (1) (1962). A person is not responsible for her criminal conduct if, at the time of the crime, "as a result of mental disease or defect [the defendant] lacks substantial capacity either to appreciate the criminality [wrongfulness] of his conduct or to conform his conduct to the requirements of the law."

${ }_{92}$ See Jodie English, The Light Between Twilight and Dusk: Federal Criminal Law and the Volitional Insanity Defense, 40 HASTINGS L.J. 1, 28 n.153 (1988-1989).

${ }^{93} 18$ U.S.C. $\S 17$ (a) (2000). "It is an affirmative defense ... that, at the time of the commission of the acts constituting the offense, the defendant, as a result of severe mental disease or defect, was unable to appreciate the nature and quality or the wrongfulness of his acts." See also United States v. Hinckley, 525 F. Supp. 1342 (D.D.C. 1981), aff'd, 672 F.2d 115 (D.C. Cir. 1982).

9418 U.S.C. § 17(b) (2000); see, e.g., ARIZ. REv. STAT. ANN. § 13-502(C) (2001).

${ }^{95}$ See infra notes 196-197. 
None of the cognitive or control tests for legal insanity is self-defining. All require substantial interpretation. To begin, how should the threshold requirement of a mental disease or disorder or defect be defined? The Supreme Court has made clear that the definition of mental disorder as a legal criterion for insanity is a legal question and within the discretion of the states. Thus, states are free to limit legal insanity to cases involving severe mental disorder or to define mental disorder in a non-traditional way, as long as the definition is minimally rational. They need not be bound by the definitions used by the mental health science disciplines, such as psychiatry and psychology. ${ }^{96}$

Moreover, there is substantial leeway in whether the tests should be read narrowly or broadly. Consider whether Andrea Yates knew what she was doing when she drowned her five children to save them from Satan's eternal torments. She did know that they were children, that drowning would kill them, and that killing them violated the law and the dominant view of morality, but she also delusionally believed that homicide was necessary to save the children from a fate far worse than premature death. In a narrow sense, she did know what she was doing and that it was morally and legally wrong. In a broader sense, however, and, assuming we believe her and her expert psychiatrists, she did not know what she was doing because she was genuinely motivated by an utterly mistaken belief that was the product of some profound abnormality. She plausibly would have been justified if the belief were true. Using words like "appreciate" or "understand," rather than "know," in a cognitive test will not help. They may signal that the test is to be interpreted more broadly-but how much more broadly and in what way? ${ }^{97}$

Control tests are even more difficult to apply. We all have a common sense understanding of when someone's perceptions or beliefs are irrational, but what does it mean to say that a person cannot control himself? If a person is having difficulty conforming to law because he is irrational, then irrationality is doing the potentially excusing work and there is no need for a separate control test. ${ }^{98}$ For example, if Ms. Yates believed

${ }^{96}$ Kansas v. Hendricks, 521 U.S. 346, 359 (1997).

${ }^{97}$ See Douglas Mossman, United States v. Lyons: Toward a New Conception of Legal Insanity, 16 BULL. AM. ACAD. PSYCHIATRY \& L. 49, 54-57 (1988). Dr. Mossman provides a thoughtful definition of "appreciate" in the context of the insanity defense, but the term does not entail his usage and the criteria he employs could by interpretation be made part of the criteria for "knowledge" or "understanding." Moreover, a court could interpret the term "appreciate" in the same general way as Mossman, but it could also make the interpretation narrower or even broader. Again, no term for the cognitive test is self-defining or talismanic.

${ }^{98}$ See Stephen J. Morse, Uncontrollable Urges and Irrational People, 88 VA. L. REV. $1025,1054-63$ (2002). 
that she had an absolute moral obligation to "save" the children by drowning them, it would indeed be difficult for her to obey the law. Here, though, the problem is her irrational belief, not a failure of self-control. In fact, lack of rationality explains most cases of failure to conform to law among people with severe mental disorder.

Control tests are often characterized as volitional, as if mental disorder has somehow disabled the agent's volitional capacities, but this locution is confusing and should be abandoned. There is no consensual definition of volition or will in any of the relevant disciplines, such as psychology or philosophy, and this formulation quickly dissolves into the intractable issues of how the brain enables the mind and how intentions are related to actions.

Perhaps one helpful way of thinking about volition is as the executory mental state that produces an action in response to an intention. ${ }^{99}$ Viewed in this way, however, virtually no one with a mental disorder has a volitional problem because people with disorders are fully able to execute the intentions that their disordered thoughts, perceptions, and desires may motivate. ${ }^{100}$ There may be some unusual cases when a symptom of mental disorder, such as anxiety, "paralyzes" a person who has a legal duty to act. In such instances, there are indeed volitional problems, but such cases are rare to the vanishing point in criminal law. There is a common sense meaning of lack of self-control, of course, but terming it a volitional problem perpetuates a conceptual and pseudo-scientific confusion.

Despite the definitional and empirical difficulties, however, some criminologists and legal philosophers nevertheless believe control tests are necessary for crimes committed by defendants with impulse disorders, such as Intermittent Explosive Disorder, ${ }^{101}$ or "disorders of desire," such as Pedophilia. ${ }^{102}$ In the former case, though, the problem is that the person intermittently appears to be unable to bring rationality to bear; thus, a cognitive test best subsumes such cases. In the latter type of case, the defendant is usually entirely in touch with reality and probably knows and

\footnotetext{
99 Among legal philosophers, this conception has been advanced best by Michael S. Moore. MOORE, supra note 65, at 113-65. Moore's view of volition, like all others, is controversial.

${ }^{100}$ Herbert Fingarette \& Anne Fingarette Hasse, Mental Disabilities and CRIMINAL RESPONSIBILITY 44-65 (1979).

${ }^{101}$ See, e.g., DSM-IV-TR, supra note 50, at 663-67; see also Ronald C. Kessler et al., The Prevalence and Correlates of DSM-IV Intermittent Explosive Disorder in the National Comorbidity Survey Replication, 63 ARCH. GEN. PSYCHIATRY 669, 669 (2006). Recent data indicate that the twelve-month prevalence of this disorder is $3.9 \%$ of the population and the lifetime prevalence is $7.3 \%$.

102 DSM-IV-TR, supra note 50, at 571-72.
} 
endorses the legal and moral code. Nonetheless, he claims that he cannot "help" or "control" his conduct.

The problem in cases of alleged lack of self-control is distinguishing the disordered person from any other agent who also wants to do something very badly that the agent should not do, such as the very greedy person tempted terribly to steal. Simply characterizing the desire as disordered in one case but not the other cannot resolve the question of control; it simply begs that question. Why should we ever excuse someone who acts wrongly in response to a very strong desire, whether that desire is normal or abnormal? Moreover, what theory or account allows us to characterize desires, as opposed to perceptions and beliefs, as irrational? ${ }^{103}$ How do we distinguish between an irresistible desire and a desire simply not resisted?

Concerns like these led both the American Bar Association and the American Psychiatric Association to recommend abolition of an independent control test during the insanity reform movement that occurred in response to the Hinckley verdict. ${ }^{104}$ One of us has argued that control cases can always be assimilated to cognitive cases in any situation in which an excuse is plausible. ${ }^{105}$ It is sufficient here, however, to recognize that control tests are problematic and do not avoid the interpretive problems that beset more familiar cognitive tests.

The relevance of mental disorder to legal insanity tests is conceptually straightforward, although evidentiary problems can arise. Insanity tests address normative issues concerning responsibility that are broader than claims involving action or mens rea, which are more factual. Moreover, they are not tests about mechanisms in the literal sense. They do not address brain anatomy or physiology, for example. They do address acting human beings who may have difficulties with cognition or control. The finder of fact needs the thickest possible description of the defendant's perceptions, thoughts, and feelings at the time of the crime in order to determine whether the legal standard for insanity is met. The fact-finder employing a cognitive or control test must thus evaluate how mental disorder affects perceptions, thoughts, beliefs, desires, and feelings. While anatomical, physiological, and other kinds of non-behavioral evidence may help the finder of fact make inferences about the defendant's psychological phenomenology, the ultimate test is behavioral, making mental disorder evidence crucially relevant.

103 Robert Nozick, The Nature of Rationality 139-40 (1993) (denying the existence of a substantive theory of the rationality of desires).

104 Am. Bar ass'n Criminal Justice Standards Comm., ABA Criminal Justice Mental Health Standards 339-42 (1989); Am. Psychiatric Ass'N, InSanity Defense POSITION STATEMENT (1985).

105 Morse, supra note 98, at 1064-75. 
Before concluding the discussion of legal insanity, it is important to clarify a persistent confusion about the insanity defense-the claim that the criminal act was "caused" by mental disorder does not mean that the agent lacked free will or that the agent was determined. Free will or the absence of determinism is neither a necessary nor a sufficient condition of insanity under any definition. No insanity defense standard requires a finding that the defendant lacked "free will" or that his behavior was "determined." These locutions are often used to signal a conclusion that the defendant was or was not legally insane, but lack of free will or determinism is not a criterion for legal insanity and does no real explanatory work. People are found legally insane because they lack rational capacity or, more controversially, because they cannot conform their behavior to the requirements of law. ${ }^{106}$ Failure to understand that free will and determinism have nothing to do with legal insanity or criminal responsibility more generally is a ceaseless source of confusion about the need and criteria for an insanity defense. ${ }^{107}$

Further, the "causal role" that mental disorder may play in criminal behavior must be properly understood. Causation in this instance means that mental disorder produced distorted perceptions, thoughts, or desires that influenced the defendant's reasons for action. It does not refer to "mechanical" causation. It has nothing to do with determinism or free will. The actions of people motivated in part by abnormal perceptions, beliefs. and desires are actions, but they may be excused if the abnormality renders the agent sufficiently irrational. Causation of behavior by abnormal beliefs, for example, is no different from, no more "causal" than, causation of behavior by normal beliefs. The only difference is that in the former case, the agent may be irrational and should therefore be excused.

Lack of rational capacity-not determinism, lack of free will, or abnormal causation-justifies the insanity defense and explains its criteria. $^{108}$

\section{E. MENS REA AND LEGAL INSANITY}

As should be clear from the foregoing Parts, the mens rea issue is entirely distinct from the legal insanity issue, even if precisely the same evidence would be relevant to adjudicating both claims. People with mental disorder are not automatons; rather, they are agents who act for

\footnotetext{
${ }^{106}$ Stephen J. Morse, The Non-Problem of Free Will in Forensic Psychiatry and Psychology, 25 LAW \& BEHAV. SCI. 203, 210-12 (2007).

107 See, e.g., id. at 219-20; Slobogin, An End to Insanity, supra note 86, at 1222, 1238 (implying that causation is an excuse and that determinism plays an analytic role in insanity determinations).

${ }^{108}$ See supra discussion about determinism and causation at notes 106-07.
} 
reasons. Their reasons may be motivated by distorted perceptions and beliefs, but they do form intentions and have knowledge of what they are doing in the narrow, most literal sense. Thus, it is very uncommon for mental disorder to negate all mens rea, even if the defendant is profoundly delusional, as Daniel M'Naghten and Andrea Yates presumably were.

In some rare cases, as we have already discussed, evidence of mental disorder might negate mens rea because the mental state it produces will be flatly inconsistent with the mens rea required by the definition of the crime or because it indirectly helps to explain why mens rea was not formed on that occasion. ${ }^{109}$ In these cases, the same evidence that a defendant was delusional may both negate mens rea and support a finding of legal insanity, but the questions being answered by the evidence are different. ${ }^{110}$

$$
\text { IV. CLARK V. ARIZONA }{ }^{111}
$$

\section{A. BACKGROUND}

In the early morning of June 21, 2000, Eric Clark, a seventeen-yearold resident of Flagstaff, Arizona, was riding around in his pickup truck blaring loud music. ${ }^{112}$ Responding to complaints about the noise, Officer Jeffrey Moritz, who was in uniform, turned on the emergency lights and siren of his marked patrol car and pulled Clark over. ${ }^{113}$ Moritz left the patrol car and told Clark to remain where he was. ${ }^{114}$ Less than a minute later, Clark shot and killed Moritz. ${ }^{115}$

Clark was charged with intentionally killing a police officer knowing that the officer was acting in the line of duty. ${ }^{116} \mathrm{He}$ did not contest the shooting and death, but he claimed that as a result of paranoid schizophrenic delusions, he lacked the required mens rea for the crime charged (the intent to kill a person and the knowledge that the victim was a police officer) and that, in any event, he was legally insane. ${ }^{117}$

\footnotetext{
109 See supra text accompanying notes 71-76.

${ }^{110}$ For example, if Clark really believed he was killing an alien impersonating a police officer, he lacked knowledge that he was killing a police officer, thus negating the mens rea of knowledge. For the same reason, he did not know what he was doing or that it was wrong.

111126 S. Ct. 2709 (2006).

112 Id. at 2716.

${ }^{113} \mathrm{Id}$.

114 Id.

115 Id.

${ }^{116}$ Id. All statements of the facts are taken from the Supreme Court opinion.

${ }^{117}$ Id. at 2717-18.
} 
Substantial evidence, including Clark's statements to classmates a few weeks earlier that he wanted to shoot police officers, suggested that Clark knew Moritz was a police officer and that he had planned just such a shooting. He had even arguably lured Officer Moritz by driving his truck with its radio blaring in a residential area. On the other hand, Clark presented testimony from family, classmates, and school officials about his bizarre behavior during the preceding year, including rigging his bedroom with fishing line, beads, and chimes to warn him of intruders, and keeping a bird in his car to warn him of airborne poison. ${ }^{118}$ These actions were plausibly a result of his paranoid delusions. Indeed, there was lay and expert testimony that Clark thought Flagstaff was populated with "aliens," including some that were impersonating police officers, that the aliens were trying to kill him, and that only bullets could stop the aliens. ${ }^{119}$ The defense expert also testified that Clark may have turned the radio up to drown out auditory hallucinations. ${ }^{120}$

The operative Arizona legal insanity test under which Clark was tried was limited to the cognitive right/wrong test: once the burden of production was met, the defendant had the burden of proving by clear and convincing evidence that "at the time of the commission of the criminal act [he] was afflicted with a mental disease or defect of such severity that [he] did not know the criminal act was wrong." 21 The operative rule concerning the admission of evidence of mental disorder to negate mens rea was based on an Arizona Supreme Court decision, State v. Mott, which held that psychiatric testimony was inadmissible to negate specific intent and that evidence of mental disorder, short of legal insanity, was not admissible to negate any mens rea element. ${ }^{122}$

At a bench trial, the judge permitted introduction of all the lay and expert testimony about Clark's mental disorder at the time of the crime. ${ }^{123}$ He ultimately ruled, however, that Mott barred him from using it to consider mens rea and that he could consider this evidence only to decide the issue of legal insanity. ${ }^{124} \mathrm{He}$ found Clark guilty of first degree

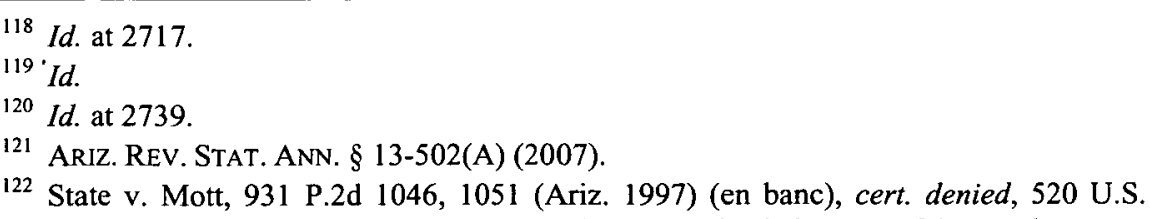
1234 (1997). The Arizona Supreme Court mischaracterized the use of battered woman syndrome evidence offered to negate mens rea as a "diminished capacity" defense. Id. at 1050. It then held, consistent with its mistaken premise, that the Arizona legislature had implicitly rejected that defense when it refused to recognize generalized diminished capacity and ruled that the evidence could be excluded. Id.

${ }^{123}$ Clark, 126 S. Ct. at 2717.

${ }^{124}$ Id. 
murder. ${ }^{125}$ Although the judge also specifically found that Clark was suffering from paranoid schizophrenia and had distorted perceptions at the time of the crime, he nonetheless found Clark legally sane because he concluded that Clark knew his actions were wrong. ${ }^{126}$

Clark appealed on the grounds that the Mott rule violated procedural due process and that Arizona's narrow insanity defense (which, as mentioned above, included only one of the two disjunctive M'Naghten prongs) violated substantive due process. ${ }^{127}$ The Arizona court of appeals affirmed the conviction, the Arizona Supreme Court denied certiorari, and the United States Supreme Court granted certiorari to decide "whether due process prohibits Arizona from thus narrowing its insanity test or from excluding evidence of mental illness and incapacity due to mental illness to rebut evidence of the requisite criminal intent. ${ }^{\prime 28}$

\section{B. THE INSANITY ISSUE}

Clark argued that the full M'Naghten rule was the minimum test necessary to satisfy due process and that Arizona's truncated test was therefore unconstitutional. Writing for the five-Justice majority, Justice Souter rejected this claim, concluding that the full M'Naghten rule is not a fundamental principle of justice subsumed by the Due Process Clause. ${ }^{129}$

The Court correctly noted that the history of legal insanity defenses in this country demonstrates substantial diversity of language and interpretation within the broad cognitive and control categories. As Justice Souter pointed out, insanity definitions vary widely across the United States, and four states have abolished the defense entirely. ${ }^{130}$ The Court also observed that the test for legal insanity is not a test for mental disorder. The tests for insanity and disorder have been devised for different purposes-assessing criminal responsibility and justifying mental health treatment-and there is controversy about both. This is inevitable because the test for legal insanity is a matter of policy. The Court concluded that because there is so much variation, "no particular formulation has evolved into a baseline for due process, and...the insanity rule, like the

${ }^{125} I d$. at 2718.

126 Id.

127 See supra note 90 and accompanying text.

${ }^{128}$ Clark, 126 S. Ct. at 2718.

${ }^{129}$ Id. at 2715. Chief Justice Roberts and Justices Scalia, Thomas, and Alito joined Justice Souter's majority opinion. Justice Breyer concurred in the majority's analysis, but dissented from the result because he would have remanded the case to let the Arizona courts apply the new rule announced by the Court. Justice Kennedy wrote the dissent, in which Justices Stevens and Ginsburg joined.

${ }^{130}$ Id. at 2721. 
conceptualization of criminal offenses, is substantially open to state choice." 131

Although reasonable people might believe that Arizona's truncated insanity test is not optimally just, the Court's holding on this issue-that due process does not require any "single canonical formulation of legal insanity"132 - seems plainly right, especially after Mullaney and Egelhoff. ${ }^{133}$ But in the course of reaching this unremarkable conclusion, the Court may have unwittingly confounded the two M'Naghten prongs.

In its original characterization of the disjunctive M'Naghten rule, as well as in its categorization of types of insanity rules, the Court referred to knowledge of the nature and quality of one's act as a question of "cognitive capacity," and knowledge of right and wrong as a question of "moral capacity." "134 In fact, both are cognitive questions, and indeed that is why both are usually alternative prongs of cognitive tests such as M'Naghten. They differ only in the object of the knowledge required. Moreover, mental disorder seldom disables a person's moral compass. The person may be making a "moral mistake" because his or her perceptions and beliefs are distorted by disorder, but the moral sense generally remains intact. Andrea Yates's delusions might genuinely have produced the belief that her behavior was morally justified, but her moral capacity was hardly disabled. Indeed, one could view her act as an indication that her moral sense was perfectly intact, albeit driven by a delusional belief.

The Court also consistently referred to control tests as "volitional" and characterized them as asking "whether a person was so lacking in volition due to a mental defect or illness that he could not have controlled his actions." $" 135$ We recognize that it is common to refer to control tests as volitional, but, as we argue above, this is a confused locution that should be abandoned. ${ }^{136}$ Whether Clark thought he was killing an alien to save himself or thought he was killing an officer because he was angry at the police, his volition or will perfectly and competently executed the intention he formed. Yates perfectly executed her intention to kill, motivated by her desire to save the children from Satan's eternal torments. Both may have experienced grave difficulty conforming to the law because they suffered profound delusions about the nature of the world, but in neither case was a defect of will the source of the problem.

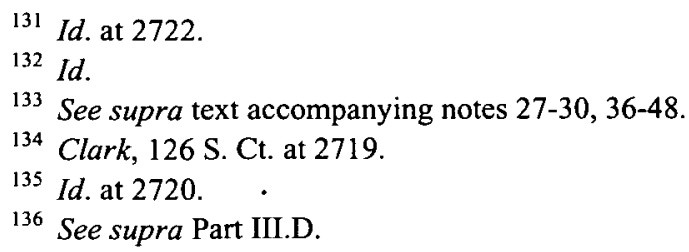


The Court also decided that the narrow Arizona legal insanity rule was constitutionally acceptable because evidence of so-called cognitive incapacity-lack of knowledge of what one was doing-is relevant to the right/wrong test and has the same significance for both. ${ }^{137}$ The Court recognized that one might show lack of moral knowledge without showing lack of factual knowledge about what one was doing, but it correctly observed that lack of the latter was sufficient to show lack of moral knowledge. ${ }^{138}$ After all, if the agent does not know what he is doing, he cannot rationally know that it is right or wrong. Indeed, the Court interpreted Arizona's legislative narrowing of the rule as a streamlining change rather than as a genuinely substantive alteration. ${ }^{139}$ Even under the narrow rule, then, all evidence of lack of factual knowledge would apparently be relevant and admissible, as it was at trial.

\section{THE MENS REA ISSUE}

Clark's second due process claim was a challenge to the constitutionality of the Arizona rule, announced in State v. Mott, that excluded expert mental health testimony on the issue of mens rea. ${ }^{140}$ In addressing this issue, the Court's majority goes quite wrong, not only confounding mens rea and insanity, but forcing psychiatric and psychological evidence into an arbitrary system of classification that is unworkable and that had never been considered or argued by Arizona.

Although the extent of the Mott rule's evidentiary exclusion is not entirely clear, it is clear that it prevents defendants from introducing substantial, relevant, and reliable mental health expert testimony concerning whether or not the requisite mens rea was formed in fact. Recall Clark's factual claim that, as a result of delusions produced by mental disorder, he actually believed Officer Moritz was a dangerous "alien" impersonating a police officer. ${ }^{141}$ If this were true, then Clark would be simply not guilty of

${ }^{137}$ Clark, 126 S. Ct. at 2722.

138 Contrary to the Court's assertion, it is possible that a defendant might not know what he or she was doing but would know that it was wrong. For example, suppose a defendant violently attacked a person with the belief that the person was a dog. See Joseph M. Livermore \& Paul E. Meehl, The Virtues of M'Naghten, 51 MINN. L. REv. 789, 809 (1967). In such a case, the defendant would not know what he or she was doing but would know that cruelty to animals was a moral and legal wrong. It is not clear from Clark's reasoning if a rule like Arizona's, which permits a conviction in such a case, would be constitutional because the Court did not envisage this possibility. It is plausible to claim that blame and punishment would be unjust in such cases. Nevertheless, although such cases are a theoretical possibility, they will be so rare that the Court's analysis is reasonable.

${ }^{139}$ Clark, 126 S. Ct. at 2723.

${ }^{140}$ Id. at 2724 .

${ }^{141}$ Id. at 2749 . 
intentionally killing a person (unless the definition of "person" was expanded to include extraterrestrials), let alone guilty of knowingly killing a police officer acting in the line of duty (again, unless the definition of "police officer in the line of duty" was expanded to include an extraterrestrial whose alien line of duty was to impersonate a police officer).

The trial judge permitted Clark to introduce expert testimony that addressed the mens rea question, but ultimately decided that Mott barred him from considering this testimony in reaching a verdict on the homicide charge. ${ }^{142}$ Thus, Clark was functionally prevented from using relevant and reliable testimony to cast a reasonable doubt about the mens rea for the crime charged.

\section{The Tripartite Evidence Construction}

In order to insulate the Mott rule from Clark's due process claim, the Supreme Court majority mischaracterized Arizona's rule. Instead of holding that Mott excluded expert mental health testimony on the issue of mens rea, the Court ruled that Mott actually applied only to two of the three types of distinguishable mens rea evidence: observation evidence, mentaldisease evidence, and capacity evidence. ${ }^{143}$ The Court then upheld the rule against a due process attack simply by announcing that the Arizona courts could not possibly have intended it to apply to the first category. ${ }^{144}$

The majority defined the first category, "observation evidence," "in the everyday sense [as] testimony from those who observed what [a defendant] did and heard what he said; this category would also include testimony that an expert witness might give about [the specific defendant's] tendency to think in a certain way and his behavioral characteristics." "145 The Court pronounced that this first category of mens rea evidence was admissible despite Mott and could be presented by either lay or expert witnesses. ${ }^{146}$

The second category, "mental-disease evidence," was defined as "opinion testimony that [a defendant] suffered from a mental disease with

${ }^{142} I d$. at 2717-18. A psychiatrist called by the defense not only testified that Clark was suffering from paranoid schizophrenia with delusions at the time of the killing and was therefore insane, but also that because of those delusions, Clark could not have formed the intent to kill Officer Moritz with knowledge that Moritz was a policeman. Id.

${ }^{143}$ Id. at $2724-26$.

${ }^{144}$ Id. at $2725-26$

${ }^{145} \mathrm{Id}$. at 2724.

${ }^{146} I d$. at 2725 . It is interesting that the majority constructs these categories of mens rea evidence without being explicit about whether they are meant to describe the actual limits of Mott (an odd thing for a federal court to be doing when the rule at issue was invented by a state court) or the constitutional limit of Mott's reach. It must be the latter, but the majority's reluctance to admit it is puzzling. 
features described by the witness." 147 That is, such testimony provides general information about the mental disorder from which the specific defendant allegedly suffers. The Court pronounced this kind of evidence, which is almost always provided by mental health experts, inadmissible under Mott.

The majority defined the third category, "capacity evidence," as evidence about a defendant's "capacity for cognition and moral judgment (and ultimately also his capacity to form mens rea)." evidence provided by experts, and, as with category two, the Court upheld Mott's exclusion of this type of mens rea evidence.

In upholding the constitutionality of Mott's bar to mens rea evidence in categories two and three, the Clark majority mistakenly refers to barring these types of evidence on the legal insanity issue, not mens rea: "Thus, only opinion testimony going to mental defect or disease, and its effect on the cognitive or moral capacities on which sanity depends under the Arizona rule, is restricted." 149 Is this astonishing error typographical, or a deeper reflection of the majority's own confusion between these two very different principles? ${ }^{150}$

The majority's unprecedented tripartite construction fails to do the theoretical work necessary to draw a sensible line between which types of expert mental disorder evidence states may and may not exclude. This classification was not part of Arizona law (or any state law we know about) and cannot be found in any Supreme Court precedent. If that were not enough, neither of the parties or amici ever suggested such a construction in their briefs or at oral argument.

Moreover, this construction not only allowed the Court's majority to find the artificially restricted rule constitutional, it also allowed it, alternatively, to conclude that Clark failed to preserve his constitutional argument on this point because he never asked the trial court to admit mental state evidence in category one despite the exclusion of categories two and three. ${ }^{151}$ As Justice Kennedy aptly put it in his dissent, "Seizing upon a theory invented here by the Court itself, the Court narrows Clark's claim so he cannot raise the point everyone else thought was involved in the case." $" 152$

${ }^{147}$ Id.

148 Id.

149 Id. at 2726 (emphasis added).

150 This is not an isolated example of the majority conflating insanity and mens rea. As discussed infra in the text accompanying note 154, they do it again later in the opinion.

151 Clark, 126 S. Ct. at 2727.

152 Id. at 2738 (Kennedy, J., dissenting). 
Justice Kennedy, and to some extent Justice Breyer in his concurrence, also recognized that the majority's tripartite classification quickly breaks down in practice and therefore ends up being an unworkable solution to this constitutional problem. ${ }^{153}$ There are clear, core cases of each type, but testimony rarely comes so neatly packaged. For example, sound empirical evidence about the characteristics of people suffering from a particular mental disorder is based on observation and is factual. In many cases, such evidence would help a finder of fact understand the behavior of a defendant who suffers from that disorder, even though the evidence comes from the observations of others. That is to say, much of the inferential expert evidence Justice Souter believes Mott may constitutionally exclude is actually observational evidence that could not have been excluded had the observations been about the defendant himself. Would experts be allowed to testify about their own observations of the defendant, but then not be permitted to testify about the features of a recognized diagnostic category that help explain those observations?

All clinical judgments in medicine, psychiatry, and clinical psychology are, by their very nature, informed by the clinician's observation of the particular patient being seen, by the accumulated wisdom of observations of other patients by that clinician and others, and by findings from empirical studies. The Court's fictitious categories of evidence not only bleed into one another, but they also seem peculiarly unable to do the important constitutional work the Court asks of them.

The Court also reasoned that Clark's due process claim depended on the application of the presumption of innocence, the presumption of sanity, and "the principle that a criminal defendant is entitled to present relevant and favorable evidence on an element of the offense charged." 154 The Court noted, as it was bound to under Winship, that the presumption of innocence could only be overcome by proof beyond a reasonable doubt of all elements, including mens rea. This is boilerplate.

The Court then observed that the presumption of sanity is universal in some form, but confusingly mischaracterized it as a presumption "that a defendant has the capacity to form the mens rea necessary for a verdict of guilt and the consequent criminal responsibility." 155 Once again, the Court confused mens rea with insanity, this time in the heart of the opinion explaining why Arizona may constitutionally prevent a defendant from introducing category two and three evidence to negate mens rea. Indeed,

\footnotetext{
${ }^{153}$ Id. at 2737-38 (Breyer, J., concurring), 2738-39 (Kennedy, J., dissenting).

${ }^{154}$ Id. at 2729 (majority opinion).

${ }^{155}$ Id. at 2730 .
} 
the whole presumption-of-sanity discussion in this section of the opinion is irrelevant to Clark's mens rea claim.

The Court not only blurred the distinction between mens rea and insanity, but also made wholly inconsistent observations about the relationship between the two. It rejected the argument that mens rea and insanity are "entirely distinguishable," yet obscurely noted that insanity "trumps" mens rea, suggesting that they are not functionally distinguishable because the former subsumes the latter when both are claimed. ${ }^{156}$

The majority correctly acknowledged that evidence of the defendant's state of mind at the time of the crime might indicate the defendant's actual mental state and the presence of an enduring incapacity to form the requisite mens rea. ${ }^{157}$ Given that acknowledgment and the majority's recognition of a defendant's constitutional right to present evidence that negates an element, how did the Court conclude that Arizona could constitutionally deprive Clark of that right? The majority reached this conclusion by claiming that Arizona could permissibly "channel" mental disorder evidence solely into the insanity issue and out of the mens rea issue because Arizona had legitimate state interests in such channeling.

\section{The Channeling Argument}

The Court accepted Clark's characterization of the Mott rule as a rule of evidence rather than as a reworking of the elements of homicide, and conceded again that the evidence was relevant. As Montana v. Egelhoff ${ }^{158}$ makes clear, states may of course preclude relevant defense evidence-even evidence that rebuts an element of the offense-if the state has a legitimate purpose in excluding the evidence. What were Arizona's "legitimate purposes" in channeling some forms of expert mental state evidence into insanity and away from mens rea? Here is where the Court's reasoning goes radically wrong.

The Court's first identified "legitimate reason" is yet another example of its conflation of mens rea and legal insanity. In the part of the opinion addressing the insanity issue, the Court reaffirmed Arizona's authority to define legal insanity as it wishes and to place the burden of persuasion for this defense on the defendant. ${ }^{159}$ Consequently, the Court reasoned that if Arizona is to have this authority in practice as well as in theory, it "must be able to deny a defendant the opportunity to displace the presumption of

\footnotetext{
${ }^{156}$ Id. at 2731 n.38

${ }^{157}$ Id.

${ }^{158}$ See supra text accompanying notes 36-48.

159 Clark, 126 S. Ct. at 2732-33.
} 
sanity more easily when addressing a different issue ...."160 This is a nonsequitur that is based on confusions about the presumption of sanity and "capacity" that we addressed above. ${ }^{161}$ There is no presumption of sanity applicable to the mens rea elements. Even if there were, the presumption must be rebuttable and a crucial method of rebuttal in a case involving severe mental disorder would be by the introduction of expert testimony.

Mental disorder and capacity evidence used to negate mens rea could result in acquittal simply by presenting a reasonable doubt about mens rea, whereas the same type of evidence used to prove legal insanity would succeed in Arizona only if the defendant convinced the finder of fact of his insanity by a preponderance of the evidence. Such a difference is not a "displacement" of the presumption of sanity, however. It is simply a logical consequence of the interaction between the structure of criminal culpability and Winship's constitutional requirements. Criminal responsibility can be avoided either by negating an element of the crime charged or by establishing an affirmative defense. Permitting an affirmative defense, as the Court recognizes, does not remove the State's obligation to prove the elements beyond a reasonable doubt. Clark's claim does not undermine Arizona's right to define legal insanity as it wishes.

The Court's second "legitimate purpose" is Arizona's desire "to avoid a second avenue for exploring capacity, less stringent for a defendant."162 Mens rea is not about "capacity" or about "criminal responsibility" more broadly; it is about whether a mental state required by the definition of the crime charged was in fact formed. Contrary to the Court's assertion, permitting a jury to use mental-disease or capacity evidence to decide if there is a reasonable doubt about mens rea is not "in functional terms ... analogous to allowing jurors to decide upon some degree of diminished capacity to obey the law ... that would prevail as a standalone defense." "63 Negation of mens rea is not an independent "defense" of "diminished capacity." Mens rea negation is simply a straightforward denial of the prima facie case that needs no special name. The question of "diminished capacity" is the province of the insanity defense or mitigating evidence at sentencing, not mens rea negation. The state undeniably has the authority to reject a partial responsibility mitigating doctrine, but this was not what Clark was requesting. The majority's constant blurring of the mens rea and legal insanity issues simply perpetuates this confusion.

\footnotetext{
${ }^{160}$ Id. at 2732.

161 See supra text accompanying notes 155-56.

${ }^{162}$ Clark, 126 S. Ct. at 2733.

${ }^{163} \mathrm{Id}$.
} 
The Court then articulated a third legitimate purpose: Arizona has made a determination that mental state evidence is just too unreliable and risky to be the basis of a complete defense under which a defendant is entirely acquitted and unconditionally freed. Now, at last, we are at the heart of Arizona's real concerns. In fact, the Court identified three separate such risks: (1) the controversial character of some categories of mental disease; (2) the potential of disease evidence to mislead; and (3) the danger of according greater certainty to capacity evidence than experts claim for it. ${ }^{164}$ The Court's general conclusion about the second and third risks was that shifting the burden of persuasion to the defendant by channeling the evidence into the insanity issue would reduce the risk that misleading evidence would lead to incorrect verdicts.

The Court is certainly correct and has noted on many occasions that there is great debate about the concept of and criteria for mental disorders. ${ }^{165}$ As a result, caution is warranted "in treating psychological classifications as predicates for excusing otherwise criminal conduct." ${ }^{166}$ This is true enough, but the same argument applies to any use of diagnostic information, which is routinely admitted in a wide array of civil and criminal law contexts, including the insanity defense. The Court's argument proves too much.

Moreover, the defendant is not seeking to excuse his conduct. This might be a valid reason for channeling in the other direction: allowing mental disorder evidence for mens rea and disallowing it for insanity. It is not a justification for channeling in the Mott direction, which allows excusing evidence but disallows evidence that would exonerate because it defeats the prima facie case. If Eric Clark genuinely thought that he was killing an alien impersonating an officer, he is simply not guilty, full stop, of homicide. He killed a person, but he did not commit the crime of homicide of a police officer, which requires that he intentionally kill a person with knowledge that the victim was a police officer.

The second risk--that mental-disease, i.e., general diagnostic, evidence may lead to the incorrect conclusion that the defendant lacks capacity to form mens rea when in fact he possessed mens rea-is true to a degree. Avoiding such a risk is no doubt a legitimate state interest. There

164 Id. at $2734-36$.

165 See supra Part II.

166 Clark, $126 \mathrm{~S}$. Ct. at 2734 (emphasis added). One of us is a long-time critic of the use of diagnostic information in civil or criminal cases. Stephen J. Morse, Crazy Behavior, Morals and Science: An Analysis of Mental Health Law, 51 S. CAL. L. REv. 527, 604-15 (1978) [hereinafter Morse, Crazy Behavior]; Stephen J. Morse, Failed Explanations and Criminal Responsibility: Experts and the Unconscious, 68 VA. L. REV. 971, 1055-70 (1982) [hereinafter Morse, Failed Explanations]. 
is great heterogeneity in psychiatric diagnostic categories and imperfect fit, as the American Psychiatric Association recognizes, between those categories and legal questions. ${ }^{167}$ Testifying experts, alas, do not always confine themselves to providing rigorously confirmed evidence about the characteristics of people like the defendant, and instead fall into the trap of using diagnostic terms that do not inform the legal issues. It is all too easy for professionals and lay people alike to make the mistake of begging legal questions based on a psychiatric or psychological diagnosis.

Indeed, the Court pointed out that the testifying experts in Clark made this error themselves while testifying about legal insanity: they agreed on the diagnosis of schizophrenia but disagreed about Clark's cognitive and moral capacity. ${ }^{168}$ Given the dangers of mental-disease evidence to mislead, the Court concluded, and we partially agree, that it is reasonable for a state to decide to channel the evidence to the insanity defense on which the defendant can be assigned the burden of persuasion.

This justification for complete channeling of expert evidence to the insanity issue nevertheless again proves too much. As with some of the Court's other justifications, there is no reason a state's skepticism about psychiatric evidence should begin and end with the criminal law. States use diagnostic information in a host of other legal contexts. ${ }^{169}$ If anything, the law should be more forgiving when criminal blame and punishment are at stake. Moreover, the problem arises less from the inherent tendency of diagnostic information to mislead than from confusion about the nature of the relation of such categories to a legal conclusion. Too often, as we noted above, ${ }^{170}$ people wrongly believe that if a mental disorder played a causal role, the behavior is akin to a mechanism and the defendant is therefore not responsible. Further problems arise from the failures of the trial process adequately to cabin the experts.

Note that the experts in Clark disagreed about his cognitive and moral capacities - that is, about whether he was legally insane. But insanity is a legal question to be resolved by a lay jury or judge. Why should we expect mental health experts to agree about this ultimate legal question about which they have no more expertise than lay jurors or judges? Indeed, it is for precisely this reason that expert witnesses in federal criminal trials are not permitted to offer ultimate legal conclusions about whether a defendant was legally insane. ${ }^{171}$ Simple and sensible evidentiary rules like this would

\footnotetext{
167 DSM-IV-TR, supra note 50, at xxxii-xxxiii, $\mathrm{xxxvii.}$

168 Clark, 126 S. Ct. at 2717-18.

169 See supra text accompanying note 167.

170 See supra text accompanying note 108.

171 FED. R. EvID. 704(b).
} 
diminish the misleading tendencies of diagnostic information without the need for draconian rules that prevent defendants from defending themselves with relevant and reliable evidence.

The Court's third and last argument justifying Arizona's channeling rule considered the dangers that capacity evidence allegedly presents. The Court pointed out that opinions about the capacity for moral cognition or to form mens rea are inferential judgments "fraught with multiple perils," including accurately determining the defendant's mental state at the time of the crime and properly understanding the differences between psychological and legal judgments about capacity. Moreover, testimony about the defendant's capacity to form mens rea is essentially "ultimate legal issue" testimony about which mental health experts have no special expertise. According to the Court, there is a real risk that the expert's judgment about capacity will have an apparent authority that honest mental health professionals do not claim to have. States may reasonably address these dangers by channeling capacity evidence to the insanity issue and placing the burden of persuasion on the defendant.

The Court's basic critique of capacity evidence is sound. As we have discussed previously, ${ }^{172}$ evidence about a defendant's capacity to form mens rea is extremely problematic and often lacks a solid clinical or scientific foundation. The criminal law would be better off if capacity evidence were strictly limited or even prohibited. Again, however, the Court's argument proves too much, since capacity evidence, despite its limitations, is almost everywhere admissible to address every other question in criminal and civil law to which it may be relevant. ${ }^{173}$ Why permit its limitation here, when so much is at stake for the criminal defendant? Furthermore, permitting an expert to give an opinion about legal insanitywhich experts are permitted to do almost everywhere-is a fortiori ultimate issue testimony, which the Court rejects concerning the mens rea issue.

Moreover, the Court's capacity argument was marred by providing all its examples from the context of legal insanity, yet again blurring the two doctrines. The ultimate issue of legal insanity is considerably less factual than the ultimate issue of mens rea. The former does depend on a factual understanding of the defendant's mental state at the time of the crime, but the finder of fact ultimately must make a normative moral judgment that is not straightforwardly factual because the borders of all insanity tests are fuzzy and open to interpretation. In contrast, whether a defendant formed a

172 See supra Part III.C.

173 California prohibits experts in criminal trials from offering an opinion about whether the defendant had the capacity to form mens rea. CAL. PENAL CODE $\S 22(b)$ (1998). 
requisite mens rea is, with few exceptions, ${ }^{174}$ a purely factual question. As Justice Kennedy said about Clark in his dissent, "Either Clark knew he was killing a police officer or he did not." responsibility but about empirical fact; therefore, the expert is less likely to mislead about mens rea than about legal insanity. Again, this would argue for channeling the evidence in the opposite direction.

The central problem with the majority's channeling argument is one of basic fairness. When a citizen is being threatened with the most awesome exercise of state power-criminal blame and punishment-it seems that we should be most permissive in allowing that citizen to defend himself with the same relevant and reliable evidence allowed without limitation in all other legal contexts. What is it about the criminal trial that drives the Court to tolerate defense handicaps it would not tolerate in any other arena?

It is instructive to compare the Court's approach to psychiatric evidence in another case, Barefoot v. Estelle, ${ }^{176}$ which involved a due process challenge to the admission of a prosecution expert's psychiatric opinion about a defendant's future dangerousness. The opinion was elicited in the death penalty phase of a capital trial and was based entirely on the psychiatrist's response to the prosecutor's hypothetical questions. Barefoot claimed, with the support of all the relevant mental health organizations as amici, that clinical predictions by mental health professionals of a defendant's future dangerous conduct were so inaccurate that they would inevitably lead to erroneous sentences. ${ }^{177}$ Although capital punishment was at stake, the Court upheld the admission of such predictions and ruled that the deficiencies of the testimony went simply to its weight and could be addressed by cross-examination. ${ }^{178}$

All the same arguments the Court mounts in Clark against mentaldisease and capacity evidence apply a fortiori to predictions of dangerousness, and there is no reason the same remedy that saved the potentially misleading evidence in Barefoot-vigorous cross-examination to expose its defects - could not apply equally in Clark. How can it be fair to let the state present problematic mental health evidence to support imposition of capital punishment but deny the defendant the right to use similar evidence to defend himself against a charge that he even committed a crime?

174 For example, the "premeditation" standard that in many jurisdictions makes an intentional killing a first degree murder often involves some degree of normative evaluation. Hate motivation for hate crimes is another example.

${ }^{175}$ Clark v. Arizona, 126 S. Ct. 2709, 2743 (2006) (Kennedy, J., dissenting).

176463 U.S. 880 (1983).

177 Id. at 898-901.

${ }^{178}$ Id. at 903. 
The Court in Clark never satisfactorily addresses this basic issue of fairness, or the extraordinary degree to which these kinds of channeling rules compromise the right of citizens to demonstrate their innocence. Clark may or may not have believed that Officer Moritz was an alienindeed, the trial judge concluded that he did not. If the trial judge really did not consider the relevant and reliable expert evidence that Mott excluded, Clark did not have a fair chance to cast reasonable doubt on the mens rea necessary to convict him of first degree murder.

\section{THE CONSTITUTIONALITY AND WISDOM OF ABOLISHING MENS REA AND LEGAL INSANITY}

We consider in this Part the question of whether due process mandates the requirement of mens rea for prima facie guilt and an insanity defense, and, even if the answer is "no," whether states should nevertheless retain these doctrines. After all, if states are or should be free to abolish these doctrines entirely, defendants like Clark will be hard-pressed to argue that states may not impose reasonable limitations on them, including truncating the $M^{\prime}$ Naghten test or channeling most expert mental abnormality evidence into insanity.

\section{A. ABOLISHING MENS REA}

We will not linger over whether states may constitutionally abolish mens rea. This has been an unresolved question of constitutional law ever since the emergence of the regulatory state and the concomitant growth and acceptability of strict liability crimes. ${ }^{179}$ Nonetheless, it has been clear at least since Morrisette $v$. United States ${ }^{180}$ that mens rea is essential to criminal law, and that states and Congress bear a heavy burden of justifying departures from it. Nevertheless, the Supreme Court has never crossed the line from "essential" to "constitutionally required," even for common law crimes at the core of criminal law whose mens rea elements predated the Constitution.

Part of the reason the Supreme Court has never done this is that no legislature, to our knowledge, has ever been so bold as to purport to convert a serious common law crime into a strict liability crime. Consequently, this

179 See, e.g., United States v. Dotterweich, 320 U.S. 277 (1943) (upholding strict liability and punishment for up to a year for shipping misbranded pharmaceuticals); United States v. Balint, 258 U.S. 250 (1922) (upholding strict liability and punishment for up to five years for selling controlled substances without the order form required by the Narcotic Act of 1914).

${ }^{180} 342$ U.S. 246 (1952). 
difficult constitutional question has lingered at the edges of justiciability, drawing the considerable attention of academics but not courts. ${ }^{181}$

Clark is especially disappointing because, unlike any of the other handful of cases decided by the Court in this context, it was tailor-made for exposition about the constitutional pedigree of mens rea. The Court could have made short shrift of Clark's attack on the channeling rule by announcing that Arizona was constitutionally free to abolish mens rea entirely, and thus could constitutionally limit evidence that would negate mens rea. It could even have upheld the rule while acknowledging that Arizona was not free to abolish mens rea. Instead, it avoided the issue entirely, at considerable intellectual cost. ${ }^{182}$

We see no reason to think the Court will depart from the deference-tostates course charted in Patterson, Egelhoff, and Clark, ${ }^{183}$ but, to the extent the constitutional question requires a defense of mens rea as a core principle of blameworthiness, we gladly take up the challenge. We do so despite enduring skepticism about substantive due process ${ }^{184}$ and about the constitutional authority of federal courts to interfere in such a fundamental and traditional state task as defining crimes. If there is any such thing as a fundamental principle rooted in the common law, surely it must be the notion that common law crimes and other crimes implying moral blameworthiness require mens rea, and that the state may not exercise its awesome punitive power to punish mere accidents.

Indeed, robust doctrines of mens rea antedated the common law, and although there are of course cross-cultural and temporal variations, the

${ }^{181}$ Compare Herbert L. Packer, Mens Rea and the Supreme Court, 1962 SUP. CT. REV. 107 (suggesting constitutional limits to the legislative abolition of mens rea), with Louis Bilionis, Process, the Constitution, and Substantive Criminal Law, 96 MiCH. L. REv. 1269, 1278-79 (1998) (calling the notion that individual blameworthiness is central to criminal law a "myth"). Complicating the debate is the impact of punishment theory. Some commentators have argued that a retributionist might, in some circumstances, care less about mens rea than a rehabilitationist. See, e.g., Kenneth W. Simons, When Is Strict Criminal Liability Just?, 87 J. CRIM. L. \& CRIMINOLOGY 1075 (1997). Though this detour is beyond the scope of this article, we must mention here that neither of us, who count ourselves as essentially in the retributionist camp, shares the idea that mens rea is separable from blameworthiness. On the contrary, as we discuss infra in the text accompanying notes 307 to 311 , the very idea of blameworthiness likely has its roots in our evolutionary ability to recognize intentionality.

${ }^{182}$ See supra text accompanying notes 140-72.

${ }^{183}$ See supra text accompanying notes 12-19. Even after Egelhoff, some commentators remained hopeful that the Court might breathe constitutional life into mens rea. See, e.g., Richard Singer \& Douglas Husak, Of Innocence and Innocents: The Supreme Court Since Herbert Packer, 2 BUFF. CRIM. L. REV. 859 (1999). Alas, after Clark, we suggest those hopes are dashed.

${ }^{184}$ See supra note 14. 
notion that intentional acts deserve a different kind of response than accidental ones seems to be a human universal. ${ }^{185}$ Part of the confusion about the historical-legal pedigree of mens rea is that criminal law itself is a relatively recent invention. For most of civilization's history, the state simply did not concern itself with what we call "crime." With a few notable exceptions, ${ }^{186}$ the ancient remedy for wrongs done by one person against another was almost exclusively a matter of private revenge. ${ }^{187}$ Only a small number of violations - such as treason or other wrongs directed against the state itself- justified the attention of government. ${ }^{188}$ Therefore, it is misleading for commentators trying to deny the pedigree of mens rea to argue that it is an invention of English common law, ${ }^{189}$ when in fact the

185 See Paul H. Robinson, A Brief History of Distinctions in Criminal Culpability, 31 HAST. L.J. 815, 996 (1980) (noting that "[w]hile Christian thought on mens rea had a dominant influence over its development in English law, similar concepts are found in nearly all criminal laws, often without a history of Christian influence").

186 The Code of Hammurabi, for example, not only contained a comprehensive set of rules governing personal conduct, but also made violators of some of those rules answerable to the state. See Stanley A. Cook, The Laws of Moses and the Code Of Hammurabi $1-$ 19 (1903). Its place in history was earned not only because of its scope and its influence on western civilization through the Jews, but also because it was the first set of laws, and one of only a handful of known ancient laws, to make this remedial transition from private revenge to state-imposed punishment. Id. The Laws of Moses and the Justinian Code are two other famous examples of law codes that continued civilization's evolution from private revenge to state punishment. Id; see also O.F. Robinson, Criminal Trials, in A COMPANiON TO JUSTINIAN'S INSTITUTES (Ernest Metzger ed., 1998). Another example was Draco's laws from fifth-century Athens, which, in addition to their famous severity, were the first known set of Greek laws to make homicide an offense punishable by the city-state, apparently in an effort to curb a rise in Athenian revenge killings. See Douglas M. MACDowell, THE LAW IN CLASSICAL ATHENS 42-43 (1978).

${ }^{187}$ To be more precise, our modern distinctions between public and private, between crime and tort, are just that-modern distinctions. See, e.g., James Lindgren, Why the Ancients May Not Have Needed a System of Criminal Law, 76 B.U. L. REV. 29 (1996). It is rather remarkable to contemplate that trial by battle, which was a formalized kind of private revenge, was not officially abolished in England until 1819, though it had, admittedly, all but disappeared by the end of the reign of Edward III. EDWARD J. WHITE, LEGAL ANTIQUITIES 118 (1913).

${ }^{188}$ Lindgren, supra note 187 , at 39 . Justinian's Code, for example, recognized only a few crimes against the Roman public, including treason, adultery, assassination and parricide. Id.

${ }^{189}$ See, e.g., Deborah W. Denno, Criminal Law in a Post-Freudian World, 2005 U. ILL. L. ReV. 601,610 n.58 (citing 2 Frederick Pollock \& Frederic William Matiland, The History of ENGLish LAW: Before the TIME OF EDWARD I, at 470-73 (2d ed. 1968) (supporting the proposition that crimes were strict liability in England until the fifth century)). 
development of English common law marked the emergence of English criminal law itself-not mens rea. ${ }^{190}$

Our plea that mens rea must be part of any constitutionally legitimate criminal system is not so much an historical conclusion as a moral one. It is simply immoral for the state to punish accidents and intentional harms the same way. The mens rea an offender possesses expresses his or her attitudes towards the rights and interests of fellow citizens. ${ }^{191}$ Different culpable mental states justify different levels of punishment consistent with different degrees of desert. Without mens rea, no blame and punishment would be justified at all, at least for core crimes. The causal roots of that immorality may be in part biological, ${ }^{192}$ but however our concern with mens rea began, it is now a fundamental feature of our moral practices. One need not be a neo-Darwinist to understand that if "fundamental rights" or "selfevident principles" mean anything, they must include guarantees that the state should satisfy its duties under the consent-to-be-governed bargain. Neither we nor our founding or framing ancestors reasonably expected the state to be able to punish us for accidents, any more than Holmes's dog mistook kicks for stumbles.

Mens rea is so crucial to fair ascriptions of blame and imposition of punishment that we are wary of attempts to dilute it by redefinitions of elements and affirmative offenses or by evidentiary rules. Although the criminal law, as a human institution, can never guarantee perfect justice and must often balance competing moral and practical considerations, the risk of error should seldom be shifted to the defendant, thus risking wrongful conviction or wrongful conviction of a more serious crime, unless there are supremely good reasons for doing so. The presumption should be against redefinitions and evidentiary rules that undermine the values Winship protects.

There are occasions when making a claim part of affirmative defenses rather than an element of a crime may be warranted because the claim really is an excuse, or because there are good evidentiary reasons for shifting the burden of persuasion to the defendant. For example, New York's "extreme emotional disturbance" doctrine addressed in Patterson is clearly a generic partial excuse and has no necessary logical or empirical connection with homicide. Likewise, one could argue that dissociated, act-like behaviors, such as sleepwalking, should be treated as affirmative defenses rather than as part of the definition of the act element because establishing whether

190 For the evolutionary roots of mens rea, we need to look much further back than the emergence of punishing states, or even the existence of states at all. We look at those roots in Part VI.B.

191 See infra Part III.C.

192 We address this speculation in Part VI.B. 
such a state existed at the time of the crime can be extremely problematic. Treating such cases of automatism as an affirmative defense and shifting the burden of persuasion to the defendant, who is in the best position to provide the evidence, might render verdicts more accurate in such cases. Again, however, we should be wary about such rules.

\section{B. ABOLISHING THE INSANITY DEFENSE}

The authors of this Article disagree about the strength of the justification for the defense of legal insanity, but we agree about the wisdom of retaining some form of the defense. ${ }^{193}$ First things first: May a state constitutionally abolish all forms of the insanity defense? Probably.

The Supreme Court noted in Clark that it has never ruled whether an affirmative defense of legal insanity is required by due process. ${ }^{194} \mathrm{~A}$ few older state court opinions held abolition of the defense unconstitutional as a violation of fundamental fairness and the right to a jury trial. ${ }^{195}$ More recently, however, five states have abolished the insanity defense, and in four of the states the state supreme court upheld the abolition. ${ }^{196}$ In the fifth, the Nevada Supreme Court held that abolition violated due process under both the state and federal constitutions. ${ }^{197}$ In short, the constitutionality of abolishing the insanity defense is largely an open question. How should it be resolved?

Insanity as an excusing condition has as formidable a history as mens rea. ${ }^{198}$ Forms of a recognizable insanity defense were established in antiquity. Hale recognized the importance of legal insanity in the seventeenth century, and when the House of Lords later adopted the M'Naghten rules they were simply codifying what was already understood to be the common law. ${ }^{199}$ Some form of the insanity defense was almost

193 One of us (Morse) is a strong supporter of retaining an insanity defense in some form; the other (Hoffman) is less enthusiastic. We agree, however, that the defense should be retained, even if the Constitution does not require it, and that it should be defined relatively narrowly. See infra text accompanying notes 205-06.

194 Clark v. Arizona, 126 S. Ct. 2721 n.20 (2006).

195 Sinclair v. State, 132 So. 581 (Miss. 1931); State v. Strasburg, 110 P. 1020 (Wash. 1910).

${ }^{196}$ State v. Bethel, 66 P.3d 840 (Kan. 2003); State v. Herrera, 895 P.2d 359 (Utah 1995); State v. Searcy, 798 P.2d 914 (Idaho 1990); State v. Korell, 690 P.2d 992 (Mont. 1984).

${ }^{197}$ Finger v. State, 27 P.3d 66 (Nev. 2001).

198 Daniel N. Robinson, Wild Beasts \& IdLe Humours: The InSANity Defense from ANTIQUiTy to THE Present (1996); Anthony Platt \& Bernard L. Diamond, The Origins of the "Right and Wrong" Test of Criminal Responsibility and Its Subsequent Development in the United States: An Historical Survey, 54 CAL. L. REV. 1227 (1966).

${ }^{199}$ Platt \& Diamond, supra note 198, at 1233-37. Moreover, a famous earlier case had adopted the "product" test. Hadfield's Case, 27 Howell 1281 (1800). Isaac Ray's influential 
certainly part of the common law when the United States was founded and was in effect in all states at the time of the adoption of the Fourteenth Amendment. ${ }^{200}$ After M'Naghten, some type of insanity defense was universal until the $1980 \mathrm{~s}^{201}$ This suggests at least a substantially deep tradition in Anglo-American common law and in American statutes that followed the common law. Perhaps the insanity defense is so deeply rooted in our tradition that the Constitution requires its retention in some form.

On the other hand, despite the similarities among the states' different approaches, there has often been profound disagreement, and even perplexity, about the justification for the insanity defense. As a result, longstanding inquiries into cognitive and control functions have generated varied approaches across time and jurisdictions. From time to time, as in the wake of the unpopular Hinckley ${ }^{202}$ verdict, there has been intense criticism of the defense. ${ }^{203}$ Even if the brief post-Hinckley wave of abolition does not represent a discernable trend, perhaps there is no better evidence that the insanity defense is not deeply rooted than the vote of five state legislatures to abolish it. ${ }^{204}$ Moreover, the language in Powell discussing the constantly shifting tension in the criminal law's treatment of responsibility ${ }^{205}$ suggests that the Court does not believe our core traditions require the insanity defense. That language could also be interpreted to mean, however, that no specific form of the insanity defense is required, as Clark held.

In any event, the constitutional pedigree of the insanity defense is an open question, and there is no indication that the current Court will reject the plausible argument that it is not constitutionally required. In the balance of this section, we argue that the insanity defense should continue to be an essential feature of any criminal justice system that claims to provide justice

1838 treatise is also indicative of the common law lineage of legal insanity. ISAAC RAY, A TREATISE ON THE MEDICAL JURISPRUDENCE OF INSANITY (1838).

${ }^{200}$ Platt \& Diamond, supra note 198 , at 1248-50.

${ }^{201}$ Id. at $1257-58$.

${ }^{202}$ United States v. Hinckley, 525 F. Supp. 1342 (D.D.C. 1981), aff'd, 672 F.2d 115 (D.C. Cir. 1982).

${ }^{203}$ The alleged empirical, historical, and consequential reasons for dissatisfaction with insanity defense at the time were either empirically incorrect or analytically unsound. None was persuasive. Stephen J. Morse, Excusing the Crazy: The Insanity Defense Reconsidered, 58 S. CAL. L. REV. 777, 788-801 (1985).

204 The weakness of the abolitionist arguments had been fully exposed by the time the "wavelet" of abolition occurred. The point, however, is that the very fact that five states have abolished the defense and four states' highest courts have upheld abolition might be a clue about whether the insanity defense is constitutionally embedded in our deepest due process traditions. We recognize the tautological difficulties with this argument. This difficulty is evidence of the problematic nature of substantive due process.

${ }^{205}$ See Powell v. Texas, 392 U.S. 514, 535-36 (1968). 
based on desert and blame. Indeed, we believe a robust but narrowly defined insanity defense, and other appropriate excusing conditions, will paradoxically help enhance the importance of mens rea and the understanding that almost all of us are sufficiently responsible for our actions to deserve blame and punishment if we offend.

The crucial normative question is whether it is unfair to blame and punish a defendant who meets the definitional elements of the crime, but whose rationality at the time of the offense was severely impaired. ${ }^{206}$ Rationality is the touchstone of responsibility, as the structure of criminal law itself indicates. All laws, criminal and civil, make sense and are functional precisely because they provide action-guiding reasons addressed to potentially rational creatures. We do not expect other animals to understand the reason for a rule or the deterrent value of punishment because other animals are not capable of the same degree of rationality as homo sapiens. There are no chimp legislatures or avian police. It is simply unfair to hold responsible, blame, and punish mentally disordered wrongdoers who are not morally responsible because they were not capable of being rational at the time of the crime.

Consider, as an analogy, the criminal responsibility of juveniles. The common law defense of infancy conclusively presumes that children younger than seven are not responsible and imposes a rebuttable presumption of lack of responsibility for those between the ages of seven and fourteen. ${ }^{207}$ The reason for this rule, of course, is that the rational capacities of young children are not formed, even though they may be entirely capable of forming and acting on intentions, and even though they might know that what they are doing is wrong. A four-year-old is perfectly capable of intending to pocket a stick of gum, and of doing so even after his or her parents have said that the child may not have it. We do not prosecute the four-year-old because we understand that four-year-olds have just begun to internalize social norms and rules, and they do not fully appreciate what it is about the world that requires items in stores to be paid for, or indeed, even what it means to "pay" for something. ${ }^{208}$

${ }^{206}$ We refer to impairment of rational capacity generally to avoid begging the question in favor of any particular legal insanity rule and because the dominant insanity rules involve rationality defects.

${ }^{207}$ LAFAVE, supra note 66 , at $485-86$.

208 That we do not allow the state to punish them does not of course mean they should not be punished as a method of instruction unrelated to genuine moral desert. The whole process of internalizing the social contract is a learning process that requires instruction and example from the moment the infant begins to realize he or she is not the center of the universe. But to subject individuals to state sanction, the intentional infliction of stigma and pain, is, at least in enlightened societies, quite a different matter that requires desert. 
Driven by the same principles, the Supreme Court has held that states may not apply their death penalties to criminally responsible capital murderers who suffered from retardation or were under the age of eighteen when they killed, ${ }^{209}$ and they may not execute defendants convicted of capital murder who are incompetent to be executed. ${ }^{210}$ In all cases, the Court pointed to factors related to the general capacity for rationality, such as the retarded person's "diminished capacities to understand and to process information" and "to engage in logical reasoning," 211 the adolescent's "lack of maturity and an underdeveloped sense of responsibility,"212 and the incompetent capital prisoner's lack of "comprehension of why he has been singled out and stripped of his fundamental right to life, ${ }^{, 213}$ or the prisoner's lack of "rational understanding" that prevents him from "comprehending the meaning and purpose of the punishment."214 The Court's language and reasoning confirm that lesser rational capacity, whether arising from normal developmental processes or abnormalities, is the reason adolescents and those with retardation are less responsible, and that some capital prisoners suffering from severe mental disorder are incompetent to be executed.

The capacity for rationality can be difficult to define. ${ }^{215}$ However it is conceptualized, it is clearly a continuum concept, ranging from almost none for two-year-olds or people with profound developmental disability or severe dementia, to fully intact for most adults with normal cognitive development. Despite conceptual and empirical disputes about mental disorder, a handful of severe mental disorders, those at the extreme of the continuum of disorders, can deprive people of the capacity to act rationally. For example, a person who delusionally believes that he is being threatened with imminent death is incapable of rationally considering whether he should act in self-defense. He is "rational" only in a narrow, instrumental sense. If his psychotic premises were true, it would indeed be rational to act in self-defense, and, in so acting, he would no doubt be acting with the

${ }^{209}$ Roper v. Simmons, 543 U.S. 551, 569 (2005) (concerning defendants who were sixteen and seventeen years of age); Atkins v. Virginia, 536 U.S. 304, 318-19 (2002) (addressing people with retardation). We may not necessarily agree with the Court's constitutional analyses in these cases, but the majority opinions in both relied heavily on behavioral science that indicates rationality differences between late adolescents and people with retardation compared to normal adults.

${ }^{210}$ Panetti v. Quarterman, 127 S. Ct. 2842 (2007); Ford v. Wainwright, 477 U.S. 399 (1986).

${ }^{211}$ Atkins, 536 U.S. at 318.

212 Roper, 543 U.S. at 569.

${ }^{213}$ Ford, 477 U.S. at 409.

${ }^{214}$ Panetti, 127 S. Ct. at 2862.

${ }^{215}$ In Panetti, after clearly adopting a "rational understanding" test, Justice Kennedy concedes that it is difficult to define. Id. at 2873. 
required mens rea. Such a narrow view of responsibility is conceptually and morally impoverished. Our hypothetical self-defender is not just making a mistake he could correct by being more careful. He is incapable of making a rational judgment about how to respond to the real world because he has grossly lost touch with that world. ${ }^{216}$

We share critics' concerns about the reliability of insanity evidence, and indeed have made the case here ${ }^{217}$ and elsewhere ${ }^{218}$ that the insanity defense's biggest problem is that it has been "over-scienced." In the end, unlike the mens rea inquiry, legal insanity is a legal and moral policy judgment, not a particular empirical fact. Our justified skepticism about the normative and even descriptive powers of psychiatry and psychology should not lead us wrong-headedly to throw the moral and legal baby out with the pseudo-scientific bathwater. Indeed, precisely because insanity is a moral construct and not a scientific one, we cannot abandon it to the scientists, especially scientists who, as we discuss below, ${ }^{219}$ misguidedly reject the possibility of individual responsibility tout court. Science may, and should, inform our normative judgments about responsibility by providing the best possible understanding of human behavior, but it cannot and should not displace them.

How many people with mental disorders should be excused depends entirely on how broadly or narrowly the insanity defense is defined and construed. No matter how limited an insanity defense may be, some defendants will have been so grossly out of touch with reality at the time of the crime that an excuse is warranted because their mental disorder, as in our example of the deluded self-defender, interferes with their rationality even if it does not interfere with their formation of mens rea. It is precisely

${ }^{216}$ Accord Westen, supra note 6, at 154-55. Christopher Slobogin's "integrationist" alternative to the insanity defense fails to make this distinction, in part because it misunderstands the relation between negligence and mental disorder. See SLOBOGIN, MiNDING JUSTICE, supra note 86, at 51-52; Slobogin, An End to Insanity, supra note 86, at 1202,1240 ; supra note 86 and accompanying text. Providing an excuse for any defendant who would be justified if the facts he believes were true would treat the careless and crazy self-defender alike. This is normatively undesirable because the crazy defender is an irrational and therefore non-responsible agent, whereas the careless defender has failed to exercise capacities he or she possesses and thus culpably violates the rights of his or her victim. The law convicts negligent self-defenders for murder or, in more forgiving states, of voluntary manslaughter based on "imperfect self defense." Careless self-defenders are not acquitted.

217 See supra text accompanying notes 164-69.

218 Morris B. Hoffman \& Stephen J. Morse, The Insanity Defense Goes Back on Trial, N.Y. TIMES, July 30, 2006, at 13; Morse, Crazy Behavior, supra note 166, at 600-26; Morse, Crazy Reasons, supra note 57, at 189; Morse, Failed Expectations, supra note 166, at 97683.

219 See infra text accompanying note 267 and Part VI. 
because of this category of defendants that mens rea alone cannot do the work necessary for a morally coherent system of criminal responsibility.

Note that if Clark were believed, he would be the rarest of the rare, a defendant whose severe mental disorder both produced a belief entirely inconsistent with a subjective mens rea on that occasion and undermined his general capacity for rationality. Note also that without an insanity defense, Clark could still be convicted of "imperfect self-defense"/voluntary manslaughter or negligent homicide because his belief that Officer Moritz was an alien was unreasonable. This is another important reason mens rea alone is not enough-its broadest net (negligence) will catch people like Clark who are not at all being "negligent" in the ordinary sense. They are incapable of behaving more carefully because of their deluded premises, and are thus morally innocent. It is simply unjust to blame and punish them.

If successful insanity defenses, like those of Daniel M'Naghten and Andrea Yates, are so infrequent, why should states even bother with adjusting their responsibility regimens to accommodate them? $?^{220}$ The answer is that desert is a necessary justification of punishment, and the very nature of desert and responsibility is individual. No one should be blamed and punished unless they really deserve it, especially for core crimes. ${ }^{221}$ With only a very few doctrinal exceptions, we hold a defendant responsible for what he and he alone did, and for what was in his mind, and his mind alone, at the time of the doing. ${ }^{222}$ We do not generally attribute one individual's actions or intentions to others. Likewise, we will consider defenses of excuse only by applying the tests for a particular class of excuse to an individual case. Paranoid schizophrenics, as a group, are of course not necessarily excused from all criminal responsibility, but neither should they, as a group, necessarily be deemed always responsible.

As long as we agree that there might be some individuals who are perfectly capable of executing instrumentally rational intentions based on a profoundly irrational, mentally disordered loss of reality, mens rea alone

\footnotetext{
${ }^{220}$ Morse, supra note 203, at 795-801.

${ }^{221}$ C.S. Lewis made this point elegantly:
}

What can be more immoral than to inflict suffering on me for the sake of deterring others if I do not deserve it? And what can be more outrageous than to catch me and submit me to a disagreeable process of moral improvement without my consent, unless (once more) I deserve it?

C.S. LeWIS, The Problem of Pain 91-92 (1940).

${ }^{222}$ Genuine non-culpable ignorance of law, conspiracy, and felony-murder are counterexamples that stretch this principle of individual responsibility, but these doctrines are justified on purely consequential grounds and are considered exceptions to the principle in the text. 
will never be enough. Our legal system has a moral duty to identify those people and to let jurors consider whether their crimes should be excused. ${ }^{223}$

\section{ALTERNATIVES TO ABOLITION}

In this Part, we address four alternatives to the insanity defense: the mens rea approach that limits admission of mental abnormality evidence solely to the issue of mens rea formation; using mental abnormality evidence at sentencing; the "guilty but mentally ill" verdict; and a recent academic proposal for an "integrationist" approach to abolition that bears much similarity to the mens rea approach. We reject all four.

The mens rea approach, adopted in the four states that have abolished the insanity defense, is precisely the opposite of the Arizona rules that the Court approved in Clark: The insanity defense is abolished but the defendant is permitted to use evidence of mental disorder to negate the mens rea requirement of the state's prima facie case. This approach is fundamentally unfair, however, for precisely the reasons given in the preceding section and in Part III discussing the relation between mental disorder and criminal responsibility. In virtually all cases, even severely disordered defendants who are grossly out of touch with reality will form mens rea and will be convicted. Even if all subjective mens reas are negated, the defendant will still be convicted for crimes in which negligence suffices because crazy perceptions or beliefs are by definition unreasonable. This is a bizarre result. In short, an insanity defense is necessary for the criminal law to make coherent, fair assessments of blameworthiness.

A second alternative to abolishing legal insanity as an excusing defense is to limit consideration of mental disorders to sentencing. This is a kind of sentencing version of the evidentiary channeling criticized above. ${ }^{224}$ This alternative blurs the distinction between crime and punishment, and thus between blameworthiness and blame. Excusing conditions like insanity are excusing conditions precisely because they are deemed inconsistent with blameworthiness. They are defenses to the crime itself, not mitigating facts. Convicting morally innocent agents-such as the

\footnotetext{
${ }^{223}$ We are not suggesting, for example, that all religious extremists who crash airplanes into buildings should necessarily be excused from their behavior because their extremism is a form of "loss of reality." See Stephen J. Morse, The Jurisprudence of Craziness, in THE LaW AND ECONOMics of IrRational Behavior 225, 256-58 (F. Parisi \& V. Smith, eds., 2005) (considering the distinction between irrational and rational terrorists). Here again, the command of a just rule of law is to consider cases individually, to allow individual members of such groups the chance to prove they are suffering from a recognized mental disease so profound that they lost touch with reality, and then let reasonable jurors decide. There is much evil in the world whose name is not insanity-but there is some whose is.

${ }^{224}$ See supra text accompanying notes 165-73.
} 
Model Penal Code's lemon squeezer ${ }^{225}$ - cannot be acceptable in any system of criminal responsibility that claims to be based on individual blameworthiness.

Moreover, moving mental state issues from affirmative defenses to sentencing changes the decision-maker from jury to judge, at least in the vast majority of states and the federal system, where juries play no role in sentencing. Yet, as we have argued throughout this Article, the insanity inquiry is not scientific, or even primarily factual; it is a normative question about an individual's rational capacity and his or her resultant responsibility for breach of the social contract. This is a moral question best answered by ordinary people, not judges or mental health experts. Finally, because sentencing is largely discretionary, there is no guarantee that the appropriate role of mental abnormality will be considered or that individual sentencing judges will calibrate punishment properly even if they do take mental abnormality into account. Juries may not always make wise decisions in legal insanity cases, but the existence of the insanity defense will at least guarantee that mental abnormality is considered in appropriate cases.

The third modern alternative to abolishing the insanity defense is the "guilty but mentally ill" verdict ("GBMI"), which has been adopted by a substantial minority of states. ${ }^{226}$ Unlike the sentencing alternative, which considers potential diminished responsibility after the defendant has been authoritatively labeled blameworthy and responsible by a guilty verdict, GBMI has nothing to do with responsibility. In fact, the convicted GBMI defendant is found fully culpable and there is no reduction in sentence. ${ }^{227} \mathrm{~A}$ GBMI capital murderer can be executed. ${ }^{228}$ Moreover, GBMI is not a treatment tool, since mental health evaluations and treatment are routine parts of health care in every prison system. Besides, when a GBMI convict is hospitalized and successfully treated, he is then returned to prison to complete his sentence, just like any other convict.

In short, GBMI is a politically expedient "third-way" fraud. It has nothing to do with responsibility and nothing to do with treatment. It is the equivalent of a verdict of "guilty but herpes," with no guarantee that the herpes will be treated or even noticed once the defendant leaves the courtroom. Its only purpose is to give legislatures political cover and to lull jurors into mistakenly believing their GBMI verdicts might mean that defendants with mental disorder who receive this verdict will be given

225 See supra text accompanying notes 76-77.

${ }^{226}$ Clark v. Arizona, 126 S. Ct. 2709, 2721 (2006).

${ }^{227}$ RalPh Reisner, Christopher Slobogin \& ARTI Rai, LAW AND the Mental Health SYSTEM: CIVIL AND CRIMINAL ASPECTS 610-11 (4th ed. 2004).

${ }^{228}$ People v. Crews, 522 N.E.2d 1167 (IIl. 1988). 
special treatment and attention, or otherwise dealt with more mercifully at sentencing or in prison.

The fourth and final alternative we wish to consider is Professor Christopher Slobogin's proposed "integrationist" alternative to the insanity defense, which is the only reasoned, contemporary scholarly proposal for abolition of which we are aware. ${ }^{229}$ Professor Slobogin provides a critique of the present insanity defense as a crucial ground of justification for his abolitionist proposal. We therefore present a response to that critique, focusing particularly on Professor Slobogin's criticism of irrationality tests for legal insanity because these tests play a large role in our justification for the legal insanity defense. ${ }^{230}$ We then turn to the proposal itself.

Professor Slobogin accuses the dominant formulations of the insanity defense of being "overbroad" 231 and unable accurately to identify those defendants who are sufficiently irrational to be excused, ${ }^{232}$ apparently because the tests can be interpreted to excuse more people than he believes normatively deserve an excuse. He also claims that the dominant insanity tests are "whimsical" because they allegedly permit the defendant to define the scope of the excuse ${ }^{233}$ and because the justification for convicting mentally disordered people with lesser rationality problems but acquitting those with severe rationality problems is "often weak." $234 \mathrm{He}$ wonders why irrationality is an excusing condition at all. ${ }^{235}$

Professor Slobogin's criticisms betray a misunderstanding of the justifications for this standard and for the insanity defense in general. He criticizes the argument for a rationality-based justification (including one based on "appreciation") by suggesting that there is little reason to believe that severe mental disorder makes it difficult for sufferers to access and be guided by good reason. ${ }^{236}$ He draws an analogy to the difficulty proponents

229 See Slobogin, Minding Justice, supra note 86; Slobogin, An End to Insanity, supra note 86. Although Professor Slobogin's argument does not change, we will focus here on the most recent, somewhat expanded version in MINDING JUSTICE. We are grateful to Professor Slobogin for a substantive and courteous discussion of our analysis of his proposal that has clarified and sharpened our thinking.

230 Professor Slobogin's critique appears in some places to understand that determinism and "mechanical" causation by factors outside one's control are not the justifications for legal insanity. SloBOGIN, MINDING JUSTICE, supra note 86 , at 40 . His discussion nevertheless often conflates these alleged justifications with genuine justifications. Id. at 39 .

231 Id. at 24.

232 Id. at 50.

233 Id.

$234 I d$. at 38 .

235 Id. at 46.

${ }^{236}$ Id. at 47 . He criticizes an appreciation test for insanity by confusing statistical predictability with a practical reasoning excuse. See id. at 44 (noting that people with psychoses are less dangerous than is usually believed). 
of a control test have when trying to demonstrate that severe disorder makes self-control difficult, ${ }^{237}$ and suggests that the reasoning ability of people with severe mental disorder may not be substantially impaired. ${ }^{238}$

This argument fails to understand the rationality test properly. The responsibility-diminishing mental state in rationality tests consists of crazy perceptions and beliefs that are not a result of carelessness and not correctable by reason or evidence. They are the product of some abnormal process. The person suffering from such cognitive distortions may have intact reasoning otherwise, but if one's premises in practical reason are uncorrectably irrational, then the agent is incapable by definition of acting rationally in that situation. Severe mental disorder simply is the inability to access good reason in the context in which the disorder is operative. This also explains why the analogy to control problems is faulty: mental disorder is not lack of control; it is lack of rationality.

Professor Slobogin's argument about overbreadth confuses causation with excuse. All behavior is caused by the necessary and sufficient variables that produce it. Other factors, such as poverty, may play a stronger causal role in crime than mental disorder, but causation per se is not an excusing condition. ${ }^{239}$ Lack of rational capacity, not causation by some factor, is why people are excused and thus there is no danger of overbreadth by excusing defendants whose criminal behavior was produced by more causally powerful variables than mental disorder. Failure to understand this point was the central flaw in prior proposals for abolition in the wake of the Hinckley acquittal. ${ }^{240}$

How broad or narrow an excuse should be is a central normative question. It is not a valid criticism of any insanity formulation to note (correctly) that it may be interpreted too broadly or narrowly for a particular critic's taste. All tests can be misinterpreted, and one's position on the normative issue of culpability requires a normative construction, not a prescriptive broadside. We have already explained why the nature of law

${ }^{237}$ Id. at 47,49 . We share Professor Slobogin's opposition to control tests that are independent of rationality tests, but we do not share the grounds for this opposition. In particular, Professor Slobogin criticizes the "volitional" test by characterizing it as if causation and lack of control were equivalent, but this is a caricature of an adequate control test rather than an attempt to come to grips with its best form and justification. Id. at 39-41.

${ }^{238}$ Id. at $48-49$.

239 Stephen J. Morse, Culpability and Control, 142 U. PA. L. REv. 1587, 1592-94 (1994).

${ }^{240}$ See, e.g., Norval Morris, Madness and the Criminal Law 61-63 (1982). Professor Morris's argument heavily influenced the widely noted but equally misguided abolitionist proposal by the American Medical Association. Board of Trustees, Am. Med. Ass'n, Insanity Defense in Criminal Trials and Limitations of Psychiatric Testimony, $251 \mathrm{~J}$. AM. MED. ASs'N 2967 (1984). Both were criticized on these grounds. Morse, supra note 203 , at $788-97$. 
itself supports the view that rationality must be the primary responsibility condition and irrationality the primary excusing condition in both criminal and civil law. ${ }^{241}$ Professor Slobogin does not embed his critique in a concept of the person or a jurisprudence of responsibility and he gives us no moral reason to prefer his outcome to the current system. Moreover, his test suffers from the same line-drawing problems as any other test. ${ }^{242}$ Identifying the right people to excuse as legally insane is an admittedly difficult enterprise, but it is no more difficult than many other line-drawing decisions that criminal law must make. The virtue of the irrationality standard is that it provides an anchor for a meaningful normative debate, and avoids the confusion of thinking that causation or determinism is the basis of the excuse or that causation is the equivalent of compulsion. ${ }^{243}$ It does not permit the defendant to define the scope of the excuse. The finder of fact must still decide if the defendant's rationality was sufficiently impaired to meet the standard for the insanity defense.

Professor Slobogin's analogies between those suffering from severe cognitive abnormalities and others who do not, such as gang members or those with dependent personalities, ${ }^{244}$ are neither apt nor useful. All people, including people with severe mental disorders, have reasons for action, for doing what they do. Likewise, all people can have their capacity for rationality compromised by anything from fleeting emotions to profound and persistent delusions. At some point, sufficient irrationality deprives people of moral agency. Of course, as Professor Slobogin notes, if irrationality does not sufficiently affect the agent's reason for committing the crime, no excuse is warranted, ${ }^{245}$ but the irrationality standard best explains why this is so.

${ }^{241}$ See supra text accompanying note 206.

${ }^{242}$ For example, suppose, in the absence of a threat for failure to comply, a defendant hallucinates God's command to do a criminal deed or delusionally believes that God wishes him or her to commit the crime. If these facts were true, what would be the legal outcome? Justification, excuse, or neither? Cf. SLOBOGIN, MINDING JUSTICE, supra note 86, at 27. Alternatively, suppose a delusional defendant believes that his life is in deadly danger, but, unknown to the defendant, he is about to be the victim of his believed aggressor and would have had a right to defend himself if he had actually known the facts. Suppose such a defendant were not deluded. Should he be justified, excused, or neither?

${ }^{243}$ Professor Slobogin's attempt to analogize the difficulties besetting rationality and volitional assessments is marred by a failure to understand the difference between the nature of the cognitive and volitional phenomena being assessed and by a confusion between mechanical causation and causation by practical reason. See, e.g., SLOBOGIN, MINDING JUSTICE, supra note 86 , at 47,50 .

${ }^{244}$ Id. at 50.

${ }^{245}$ Id. 
Professor Slobogin also criticizes a rationality test because it might excuse psychopaths or pedophiles. ${ }^{246}$ Such people are of course not popular, and public opinion and current law do not excuse them. The argument fails to confront a genuine practical reasoning approach to these conditions, however, and there are very good arguments for questioning the responsibility of some people with these conditions on grounds of impaired rationality. ${ }^{247}$ Professor's Slobogin's criticism here borrows from his criticism of "volitional" standards, but the argument depends on a misunderstanding of volitional problems and the implicit confusion of causes and reasons. Virtually all philosophers who have addressed the issue argue that psychopaths are not morally responsible. Legal and moral responsibility may be treated differently, but if one believes that the law should not blame and punish those who are not morally responsible, there is a strong case for excusing some psychopaths. Indeed, Professor Slobogin is internally inconsistent because he earlier suggests that people who cannot understand the concepts of good and evil (i.e., psychopaths, although he does not use this term) would be excused under his proposal. ${ }^{248}$ Finally, as we discuss further below, ${ }^{249}$ unless Professor Slobogin were to accept an irrationality justification, he lacks the resources to justify his claim that older adolescents and people with retardation deserve mitigation of punishment.

We are unpersuaded by Professor Slobogin's critique of the current insanity defense in general and of the irrationality justification in particular. The irrationality justification best explains positive criminal (and civil) mental health law and it is profoundly normatively defensible. We therefore believe that Professor Slobogin's integrationist proposal can only succeed if it meets the heavy burden of showing that it is more just and more workable than the present defense of legal insanity. We conclude that, in practice, the positive integrationist proposal will not provide the proper terms for evaluating blameworthiness and will not produce justice.

246 Id. at 42,51 .

247 See SuSAN WOLF, FREEdom WITHIN REASON 120-21 (1990) (arguing that those who lack the ability to be receptive to the Good-e.g., some psychopaths - are criminally insane); Stephen J. Morse, Addiction, Genetics and Criminal Responsibility, 69 LAW \& CONTEMP. PROBS. 160, 190-95 (2006) (providing such an account for addicts, but ultimately rejecting an excuse in most cases because most addicts can be held diachronously responsible). One of us (Morse) believes that severe psychopathy should qualify for an excuse (and postacquittal commitment); the other (Hoffman) is not sure.

${ }^{248}$ SLOBOGIN, Minding Justice, supra note 86, at 27. In another part of his argument, however, Professor Slobogin says that psychopaths should be held responsible. Id. at 42 . The apparent inconsistency can only be explained by differing definitions of knowledge or understanding.

${ }^{249}$ See infra p. 1132. 
Here is the integrationist proposal itself:

A person shall be excused from an offense if at the time of the offense [by reason of mental disease or defect] he (a) lacked the subjective mental state of the conduct circumstances, or result element of the crime; (b) believed circumstances existed that, if true, would have justified the offense; (c) believed circumstances existed that, if true, would have amounted to duress; or (d) was unaware of the general prohibitions of the criminal law .... 250

Professor Slobogin essentially proposes that the same defenses that apply to other criminal defendants would be applied to defendants with mental illness and there would be no independent insanity defense. He places mental disease and defect in brackets to indicate that the language need not be part of the test.

The logic of the proposal is that mental abnormality should not be required, but this exposes an immediate analytical and normative difficulty. Defendants without mental abnormality who make mistakes about justifying or excusing conditions are not judged according to the facts and circumstances they mistakenly believed were true. They are held responsible for their errors. For example, depending on the jurisdiction, a negligent self-defender who honestly but unreasonably believes he needs to use deadly force to save his own life will be deprived of the defense altogether, or he will be convicted of manslaughter on a theory of imperfect self-defense theory or of negligent homicide. Under current law it would be unthinkable to excuse a self-defender who makes a grossly unreasonable mistake. This is precisely what Professor Slobogin's proposal requires, however, unless he limits the proposal to those suffering from a mental abnormality. If he limits the proposal to abnormal defendants to avoid the undesirable result of excusing a grossly negligent defendant, then he is implicitly conceding that there is something special about mental disorder and he must say what that is and why it requires special treatment. Of course, there is something special about mental disorder. It deprives people of rationality through no fault of their own and thus distinguishes them from simply careless people. Thus, the integrationist proposal either leads to undesirable excuses for normal defendants or it implicitly provides a special defense of legal insanity.

${ }^{250}$ Slobogin, Minding Justice, supra note 86 , at 56. Professor Slobogin would deny the defendant this defense if the defendant were responsible for having the erroneous beliefs because the person had purposely avoided treatment with the awareness that such beliefs would occur without treatment. Id. We largely agree that defendants who culpably create their own excusing condition should not be excused.

We also agree for the reasons given in Parts III and IV.C that defendants should be permitted to use evidence of mental abnormality to negate mens rea and that full negation will seldom occur. Our disagreement and discussion will be limited to the affirmative defense parts of the proposal. 
Professor Slobogin tries to avoid this problem by claiming that that the doctrines of justification and negligence have largely been subjectivized. He proposes that defendants whose wrong beliefs about reality arise from psychotic states should be treated the same as those whose errors result from culpable (unreasonable) carelessness or inattention. He is incorrect about the extent of subjectivization current law accepts. As we have already seen, the Model Penal Code does not adopt the subjectivized view of negligence that Professor Slobogin claims for it. ${ }^{251}$ Even the most individualized of all the Model Penal Code's formulations, the extreme mental and emotional disturbance doctrine that reduces murder to manslaughter, has not been interpreted as fully subjective and it has met with little acceptance in American law, even when limited. ${ }^{252}$ Moreover, Anglo-American law's most thoroughly subjectivized "reasonable person" standard, adopted by the House of Lords in the context of the provocation/passion reduction of murder to manslaughter, ${ }^{253}$ has now been abandoned because it was incoherent. ${ }^{254}$ A fully subjectivized reasonable person standard is incoherent because it is not a reasonable person standard at all. The reasonable abnormal person is simply not reasonable. ${ }^{255}$

Professor Slobogin's proposal requires abandoning objective standards for negligence, justification, and the partially objective standard for duress. Professor Slobogin is perfectly entitled to propose and argue for the desirability of such a radical change in our law, but he does not provide an argument for thoroughgoing subjectivization of the criteria for justification and negligence. Indeed, he accepts the objective standard for what facts would qualify for justification or duress, but he never explains why he is willing to accept a fully subjective standard for evaluating the reasonableness of mistakes.

To exonerate a culpably careless wrongdoer the same as a deluded wrongdoer makes a mockery of the moral differences between them. The culpably careless have the capacity to pay attention and to be as careful as we expect them to be, yet they have not exercised that capacity. They have failed to respect the rights and interests of their victims. Such failure is the essence of blameworthiness in our system of morality and law. Delusional

251 See supra note 85.

252 See KADISH ET AL., supra note 10, at 405.

253 Regina v. Smith [2001] 1 A.C. 146 (H.L.)

254 Attorney General for Jersey v. Holley [2005] 2 A.C. 580 (P.C.). Holley is a Privy Council decision that technically does not bind the House of Lords, but many of the same judges serve on both courts and it is widely believed that the Lords will follow suit.

255 See John Gardner \& Timothy Macklen, Compassion Without Respect: Nine Fallacies in R. v. Smith, [2001] CRIM. L. REV. 623 (explaining the incoherence of a fully subjective reasonable person standard). 
defendants, on the other hand, have not simply made a mistake that could have been corrected by being more careful. They are incapable of getting the facts right because they are deluded. They are quintessentially blameless in our system of morality and law. ${ }^{256}$

The integrationist approach also does not have adequate resources to address the familiar and frequent case of psychotic mental states with religious content, such as hallucinating that one is hearing God's voice or delusionally believing that God wants the person to behave in some way. Suppose that there is no apparent threat to the agent, who simply believes that he is doing God's will. Such a person would not be justified under traditional criminal law, even if the facts and circumstances were as the agent believed. The standard for the balance of evils part of the residual "choice of evils" justification is purely objective and is a strict liability criterion. ${ }^{257}$ Moreover, in some jurisdictions the agent may be convicted of a crime of negligence for negligently misappraising the situation. There is no subjectivization of the reasonable person standard. ${ }^{258}$ Indeed, Professor Slobogin generally accepts the objective part of justification because subsection (b) of his proposal acquits the defendant only if the defendant would objectively be justified if the facts the defendant believed to be true were in fact true. Thus, Professor Slobogin would have to convict these types of defendants.

For example, under Professor Slobogin's integrationist approach, Andrea Yates should be convicted of negligent homicide for the deaths of her children. Professor Slobogin says that her mistaken beliefs "presumably would have been found to justify her criminal conduct," this conclusion is simply incorrect as a matter of positive law, even if the facts and circumstances had been as Ms. Yates believed and even if she were not responsible for causing the condition of her own excuse.

Some agents, such as Ms. Yates, act for such irrational reasons that it would be unjust to blame and punish them whether or not they would be justified if the facts and circumstances were as they delusionally believed. In some cases it can be difficult to determine whether a person motivated by religious beliefs is psychotic, but this is no reason not to try to achieve justice. Nitpicking about whether they would have been legally justified if the facts and circumstances had been as they believed indicates the necessity for narrow legalistic interpretation, which seems beside the moral point in these cases.

${ }^{256}$ Indeed, they would be excused under the "insane delusion" part of the M'Naghten rules, so the integrationist approach is not needed for these defendants.

257 See, e.g., Model Penal Code And Commentaries $\S 3.02(1)$ (a) at 12 (1985).

258 Id. at 13 (referring to sec. 3.02(2)).

259 SLOBOGIN, Minding Justice, supra note 86 , at 25, 53-54. 
Consider the Yates case again. Suppose, counterfactually, that Ms. Yates would have succeeded with the choice of evils justification if the facts she believed were true. Should we excuse her because the law should hold that it is better children should die than be tormented in hell for eternity-in which case she would be excused under the "insane delusion" part of $M^{\prime}$ Naghten and no integrationist approach is required-or because Ms. Yates was an irrational agent at the time of the homicide? Again, is it morally and legally sensible to be arguing what the right legal result should be if bizarre facts were true, or should we instead be focusing on the defendant's rational capacity as manifested by her abnormal, bizarre motivating beliefs? Yates may be a sympathetic defendant, but she would have a much better chance of being excused under a sensible interpretation of a cognitive insanity defense than under the integrationist approach. To be consistent, the integrationist approach could try to subjectivize the "choice of evils" justification, but this standard would permit defendants to define the scope of their own excuse, a charge Professor Slobogin wrongly levels at rationality tests. ${ }^{260}$

The integrationist approach would also excuse a defendant if duress would have obtained if the facts and circumstances the defendant believed were true. Such cases are clinically rare, but the objection is similar to the objection to the integrationist "justification" standard. If a defendant were negligent in estimating whether he is in such a situation, the defense would be unavailable for crimes requiring negligence as the mens rea, and in many jurisdictions it might not be available at all. Either the duress standard must be entirely subjectivized for both mentally normal and abnormal defendants - an undesirable legal outcome because it would acquit many culpable, mentally normal defendants-or the legal distinction between mentally normal and abnormal defendants must be preserved.

The final part of the integrationist proposal would excuse a defendant who acted under a "general ignorance of law," by which Professor Slobogin means agents who may not be aware of the concept of crime or who cannot understand the concept of good and evil. ${ }^{261}$ Virtually no normal defendant could sustain such a claim, and, among those with mental abnormalities, as a clinical matter, only psychopaths might be able to do so. Some deluded defendants may have entirely irrational views about the parameters of crime or of the concepts of good and evil, but few abnormal defendants other than psychopaths lack all understanding of these concepts. Professor Slobogin criticizes irrationality tests for insanity as potentially excusing

\footnotetext{
${ }^{260}$ Id. at 50.

261 Id. at 27.
} 
psychopaths, ${ }^{262}$ but the integrationist approach will also excuse some psychopaths, as he himself recognizes. ${ }^{263}$

Applied to psychopaths, this is not really an "integrationist" proposal at all because it affects only mentally abnormal defendants. It is in fact a form of legal insanity defense, but it is not the best approach to these cases. The best reason to excuse psychopaths, if they should be excused at all, is not a "general ignorance of law" defense. The better justification is that psychopaths lack the capacities-empathy and guilt - that are the primary tools rational agents use to give them good reason not to harm others unjustifiably. They are irrational in that respect. If we wish to excuse psychopaths-and many do not-an interpretation of the insanity defense that permits this result is the most morally precise and common sense approach.

Finally, there is a fundamental inconsistency in Professor Slobogin's "integrationist" approach. He applauds the Supreme Court decisions categorically barring execution of capital murderers who were retarded or sixteen and seventeen years old at the time of the crime, ${ }^{264}$ and argues that it would be unconstitutional to execute defendants who suffered from mental disorder at the time of the crime. ${ }^{265}$ He also argues that mental abnormality should be a mitigating factor in sentencing generally. His primary rationale for these positions is that mental abnormality diminishes the defendant's rationality, and that such abnormality-based diminished rationality can be reasonably assessed. Just so. Professor Slobogin thus concedes that irrationality is the primary mitigating and excusing condition, but, of course, lack of rational capacity is a continuum. If a substantial lack of rational capacity mitigates responsibility for purposes of just punishment, Professor Slobogin provides no reason to deny that extreme irrationality should excuse altogether. ${ }^{266}$

A suitably drafted and interpreted insanity defense addresses the fundamental excusing condition of irrationality and provides more just results than the integrationist call for legalistic and occasionally bizarre decision making criteria. The integrationist proposal is neither more just nor more workable than a properly circumscribed defense of legal insanity.

${ }^{262}$ Id. at $42-44,51$.

${ }^{263} \mathrm{Id}$. at 82 (making this point in a later chapter addressing the death penalty). Professor Slobogin claims to have recognized this point in his earlier chapter on the insanity defense, but the citation is to an article by a different scholar, and contrary to Professor Slobogin's later claims, all discussion of psychopathy in the insanity defense chapter strongly implies that psychopaths should not be excused.

${ }^{264}$ Roper v. Simmons, 543 U.S. 551 (2005); Atkins v. Virginia, 536 U.S. 304 (2002).

${ }^{265}$ SLOBOGIN, MiNDiNG JUSTICE, supra note 86 , at $64-83$.

${ }^{266}$ Id. at 75-77. 


\section{THE FUTURE OF MENS REA AND LEGAL INSANITY}

We hope we have demonstrated the critical importance, if not necessarily the constitutional pedigree, of both mens rea and legal insanity to any morally coherent system of criminal justice, and the unfairness and unworkability of alternatives. Two problems still remain. First, there are those-both in law and science-who claim that the moral premises of criminal responsibility are quaint and unscientific remnants of a bygone era, and that advances in neuroscience are dissolving notions of blameworthiness into meaninglessness. ${ }^{267}$ Second, even if we successfully resist this physicalist and determinist onslaught, where does that leave moralists? What are the foundations of a morally grounded theory of criminal responsibility?

\section{A. THE GENERAL CHALLENGE TO RESPONSIBILITY}

Scientific, physicalist theories of the mind threaten our deeply held presumptions of intentionality and personhood and thus threaten our responsibility concepts and practices. What is happening when we "act"? What is happening when we "intend" to act? What is happening when we subjectively feel and report that we are apparently unable to "control" our acts? Until relatively recently, these questions largely inhabited the halls of philosophy and speculation. These problems were technically daunting because accessing brain structure and processes was generally rudimentary or impossible. Advances in technology now allow brain imaging that can measure the electrical and heat-producing activities of single neurons during an individual's designated activity and the accumulated mapping of that neural activity over time and over many subjects. As a result, neuroscientists announce almost daily that certain activities seem to be associated with certain areas in the brain, and that new levels of functional interconnectedness between different parts of the brain have been discovered. $^{268}$

${ }^{267}$ See, e.g., Joshua Greene \& Jonathan Cohen, For the Law, Neuroscience Changes Nothing and Everything, in LAW \& THE BRAIN 207 (Semir Zeki \& Oliver Goodenough eds., 2006); Robert Sapolsky, The Frontal Cortex and the Criminal Justice System, in LAW AND THE BRAIN, supra.

${ }^{268}$ See, e.g., B. Knutson et al., Neural Predictors of Purchases, 53 NeURON 147 (2007) (noting that the questions shoppers ask themselves-how much they want an object and how much they are willing to pay for it-are associated with activity in specific parts of the brain). As is so often the case, the media quickly and breathlessly pick up the story, most often concluding or implying that the shopper is therefore not responsible for the activity in question. See, e.g., John Tierney, The Voices in My Head Say "Buy It!" Why Argue?, N.Y. TIMES, Jan. 16, 2007, at F1. In other words, we are not brains in a vat; we are brains in a mall. 
Some people, including many neuroscientists, think that these discoveries are leading inexorably to a mechanistic, deterministic view of the brain, and thus to a mechanistic, deterministic view of human behavior in which conscious intentionality plays no role. Daniel M'Naghten did not shoot that gun; it was his finger that pulled the trigger, and his peripheral neurons that caused his finger muscles to contract, and central neurons that caused the peripheral neurons to fire, and neurons to activate neurons all the way down. M'Naghten's intentions did no work in explaining his action. These are the alleged implications of scientific advances in the understanding of human behavior that terrify many thinking people.

The seriousness of the potential challenge to the traditional foundations of law and morality from behavioral and neuroscience is best summed up in the title of an eminent psychologist's recent book, The Illusion of Conscious Will. ${ }^{269}$ Its thesis, stated most extremely, is that we delude ourselves when we think that our intentions are genuinely causal. ${ }^{270}$ The rich explanatory apparatus of intentionality is simply a post-hoc rationalization that we hapless homo sapiens construct to explain what our brains have already done. We are just mechanisms, although the illusion of conscious will may play a positive role in our lives. ${ }^{271}$ The evidence for these assertions is not all based on neuroscientific findings, and the claim that we are purely mechanisms has long been thought to follow from all

${ }^{269}$ DANiEl WeGner, The ILlusion OF CONSCIOUS Will (2002).

${ }^{270}$ Id. at $3,341-42$.

${ }^{271}$ Here is an extensive quotation from the conclusion of Professor Wegner's book, which is necessary to obtain the tenor of the assertion and to evaluate if it is internally logical:

Sometimes how things seem is more important than what they are. This is true in theater, in art, in used car sales, in economics, and-it now turns out-in the scientific analysis of conscious will. The fact is, it seems to each of that we have a conscious will. It seems we have selves. It seems we have minds. It seems we are agents. It seems we cause what we do. Although it is sobering and ultimately accurate to call all this an illusion, it is a mistake to conclude that the illusory is trivial. On the contrary, the illusions piled atop apparent mental causation are the building blocks of human psychology and social life. It is only with the feeling of conscious will that we can begin to solve the problem of knowing who we are as individuals, of discerning what we can and cannot do, and of judging ourselves morally right or wrong for what we have done

Id. at 341-42.

In more recent work, Professor Wegner appears to have softened the radical interpretation of his claim, which is that we, as persons or agents, are not really "controllers" whose mental processes cause action. Daniel M. Wegner, Who Is the Controller of Controlled Processes?, in ThE NEw UNCONSCious 19, 32 (Ran R. Hassin, James S. Uleman \& John A. Bargh eds., 2005) ("The theory is mute on whether thought does cause action."). On the other hand, Professor Wegner seems ambivalent and loathe to abandon the radical interpretation. Id. at 27 (arguing that the experience of conscious will is "normally a construction" and referring to mental causation as "apparent"). 
physicalist, naturalist, scientific views of the person, but neuroscience is the source of the most profound challenge today.

If this particular physicalist and determinist view of humans is correct that we are really not acting agents at all, the present foundations of law and morality rooted in agentic personhood would collapse. If scientific investigation can demonstrate that the alleged criteria for personhood cannot be satisfied by people as they really are constituted, the criminal law's central tenet that individuals are personally responsible for their behavior would disappear. But don't fret. This collapse-which physicalists have been predicting for centuries-is not imminent. Advances in neuroscience and related fields have revealed hitherto unimagined biological causes that predispose people to behave as they $\mathrm{do},{ }^{272}$ but the science typically supporting the more general and radical claim that conscious will is an illusion-that we do not act and therefore cannot be responsible-is either insufficient empirically or does not have the implications claimed. ${ }^{273}$

To begin, it is important to recognize that the new challenge to conscious intentionality is distinguishable from the more familiar general challenge to responsibility that determinism or causation generally presents. Even if determinism is true, we may well be the types of creatures we take ourselves to be-usually conscious, potentially rational creatures whose

${ }^{272}$ Recently published issues of prestigious journals contain illustrative examples of advances in scientific understanding of the causes of legally relevant behavior. See, e.g., Avshalom Caspi et al., Role of Genotype in the Cycle of Violence in Maltreated Children, 297 SCIENCE 851 (2002) (reporting that maltreated male children were more likely to exhibit antisocial behavior if they had a defect in the genotype that confers high levels of the neurotransmitter encoding enzyme monoamine oxidase $A$, which metabolizes various neurotransmitters linked to violence if the levels of those neurotransmitters are low); Rita $\mathrm{Z}$. Goldstein \& Nora D. Volkow, Drug Addiction and Its Underlying Neurobiological Basis: Neuroimaging Evidence for the Involvement of the Frontal Cortex, 159 AM. J. PSYCHIATRY 1642 (2002) (finding addiction involves cortical processes that result in the overvaluation of drug reinforcers, the undervaluation of other reinforcers, and defective inhibitory control of responses to drugs); J. Kim-Cohen et al., MAOA, Maltreatment, and Gene-Environment Interaction Predicting Children's Mental Health: New Evidence and a Meta-Analysis, 11 MOLECULAR PSYCHIATRY 903 (2006) (discussing how the MAOA gene influences vulnerability to environmental stress, such as childhood maltreatment); Marc N. Potenza et al., Gambling Urges in Pathological Gambling: A Functional Magnetic Resonance Imaging Study, 60 ARChIVES OF General PSYCHIATRY 828, 828 (2003) (reporting that male pathological gamblers "demonstrate relatively decreased activity in brain regions implicated in impulse regulation compared with controls" when viewing gambling cues); Murray B. Stein et al., Genetic and Environmental Influences on Trauma Exposure and Posttraumatic Stress Disorder Symptoms: A Twin Study, 159 AM. J. PsYCHIATRY 1675 (2002) (concluding that genetic factors can influence the risk of exposure to assaultive trauma and to posttraumatic stress disorder symptoms that may ensue).

${ }^{273}$ See infra text accompanying notes 276-303. 
behavior is explained by our intentions. Assuming that the truth of determinism is logically inconsistent with responsibility tout court-a controversial position in the philosophy of responsibility-we can never discover if determinism is true. Moreover, there is a respectable core position in the philosophy of responsibility-"compatibilism"-that holds that determinism is not inconsistent with responsibility. ${ }^{274}$ The legal system is in any event unlikely to abandon responsibility altogether based on a speculative metaphysical thesis. We therefore do not discuss the general deterministic challenge to responsibility.

It is important to recognize, however, that simply discovering a cause for behavior, whether it is biological, psychological or sociological, does not mean that the agent is not responsible for the behavior. All behavior has causes. If causation were an excuse, no one could ever be held responsible for any behavior. One of us has called the confused, pernicious belief that causation excuses, which is used selectively and all too frequently, the "fundamental psycholegal error."275 This error is conceptually identical to the misguided belief that determinism excuses in our positive law.

On the other hand, science may in fact be able to demonstrate that we are not the types of intentional agents that we think we are, and thus that responsibility ascriptions and all that follows from them-including criminal desert-are unjustifiable. If these doubts are accurate, compatibilism cannot save responsibility because responsibility depends on agency and the new discoveries arguably deny the possibility of agency as it is traditionally conceived. We therefore limit ourselves to addressing this form of a general radical challenge to responsibility because it is at least demonstrable in principle. ${ }^{276}$

Physicalism's relentless gnawing at the role of conscious intentionality is neither new nor restricted to science. The philosophy of mind and action has long contained arguments for various forms of physical reductionism and for eliminative materialism. ${ }^{277}$ Both types of conceptual views existed long before recent discoveries in neuroscience and psychology deepened

274 Stephen J. Morse, Reason, Results and Criminal Responsibility, 2004 U. ILL. L. REV. 363, 437 nn.207-08.

${ }^{275}$ Morse, supra note 239, at 1592-94.

${ }^{276}$ See generally Stephen J. Morse, Criminal Responsibility and the Disappearing Person, 28 CARDOZO L. REv. 2545 (2007) (addressing the two general challenges to responsibility and concluding neither poses a threat at present).

${ }^{277}$ Reductive accounts hold, simply, that mental states are as they seem to us, but that they are identical to brain states. Eliminative accounts hold that our beliefs about our mental states are radically false and, consequently, that no match between brain states and mental states is possible. See Paul M. Churchland, MATTER And Consciousness 26-34, 43-49 (Rev. ed. 1988) (explaining the arguments for and against both types of accounts). 
our understanding of how the brain and nervous system are constructed and work. Both types of views are extremely controversial.

Most philosophers of mind believe that complete reduction of mind to biophysical explanation is impossible. ${ }^{278}$ Until the conceptual revolution that allows us to solve the mind-body problem occurs-and, at present, we have no idea how the brain enables the $\operatorname{mind}^{279}$-science cannot resolve the debate, although it can furnish support for various conceptual arguments. At present, and for the foreseeable future, we have no convincing conceptual reason from the philosophy of mind, even when it is completely informed by the most recent neuroscience, to abandon our view of ourselves as creatures with causally efficacious mental states. ${ }^{280}$

Even if we cannot solve the mind-body problem, however, and thus determine if reductive accounts are true, it is possible that we might make empirical discoveries indicating that some parts of our ordinary understanding about action and agency are incorrect. Much recent argument based on current neuroscience and psychology takes this position, arguing that mental causation does not exist as we think it does. For ease of exposition, we label these approaches the "no action thesis" ("NAT"), as a way of describing their ultimate conclusion that the notion of human "action" is a neurological artifact of consciousness. The logic of these arguments is often shaky. Discovering a brain correlate, or any other cause of an action, does not mean that it is not an action. If actions exist, they have causes, including those arising in the brain.

${ }^{278}$ See, e.g., JOHN S. SEARLE, MIND: A BRIEF INTRODUCTION 88-92, 111-32 (2004) [hereinafter SEARLE, MIND]; Galen Strawson, Consciousness, Free Will, and the Unimportance of Determinism, 32 INQUIRY 3 (1989) (claiming that reductive physicalism about the mind is "moonshine"); see generally JOHN R. SEARLE, THE REDISCOVERY OF THE MIND (1992) (providing an extended argument for the irreducible reality of mind) [hereinafter SEARLE, THE REDISCOVERY OF THE MIND].

279 Paul McHugh \& Philip Slavney, The Perspectives of Psychiatry $11-12$ (2d ed. 1998); see also Carl F. Craver, Explaining the Brain: Mechanisms and the MosaiC UNITY OF NEUROSCIENCE 1 (2007) ("[O]ne frequently finds claims that neuroscientists are on the verge of explaining the mysteries of consciousness, the illusion of free will, the frailty of human memory, and the nature of the self. If neuroscience succeeds in these explanatory goals, it will revise our self-conception as radically as Copernicus' decentering of the earth and Darwin's humbling vision of our origins.")

${ }^{280}$ To claim that mental states may play a causal role in behavior does not commit one to discredited mind-brain dualism. Even if mental states cannot be reduced to brain states at the level of neurons, the mind is produced by and realizable in the brain, a position that may be termed "non-reductive monism" or biological naturalism. See SEARLE, MIND, supra note 278, at 113-14. It is an almost inevitable feature of language to sound dualistic, however. For example, when critics of dualism talk about "my" or "your brain" they imply that there is a "me" or a "you," a self that is distinguishable from one's brain. Imagine expressing that thought by talking about "the brain that is inside this skull [pointing to one's own head or the head of another]." 
The real NAT question is whether scientific experiments have shown that action is rare or non-existent, that conscious will is largely or entirely an illusion after all. Four kinds of evidence are often adduced: first, demonstrations that a very large part of our activity is undeniably caused by variables of which we are not at all aware; second, studies indicating that more activity than we think takes place when our consciousness is divided or diminished; third, laboratory studies that show that people can be experimentally misled about their causal contribution to their apparent behavior; and fourth, evidence that particular types of psychological processes seem to have their biological substrate in specific regions of the brain. None of these kinds of evidence offers logical support to NAT.

Just because a person may not be aware of all the causes for why he or she formed an intention does not mean that the person did not form an intention and was not a fully conscious agent when he did so. Even if human beings were never aware of the causes of their intentions to act and of their actions, it would not necessarily follow that they were not acting consciously, intentionally, and for reasons that make eminent sense to anyone under the circumstances.

Human consciousness can undeniably be divided or diminished by a wide variety of normal and abnormal causes. ${ }^{281}$ We have known this long before contemporary scientific discoveries of what causes such states and how they correlate with brain structure and processes. Law and morality agree that if an agent's capacity for consciousness is non-culpably diminished, responsibility is likewise diminished. As we have seen, ${ }^{282}$ some suggest that it is diminished because bodily movements in the absence of fully integrated consciousness are not "actions." Others believe that apparently goal-directed behavior that is responsive to the environment, such as sleepwalking, is action, but that it should be excused because diminished consciousness reduces the capacity for rationality. Let us assume that the former view is correct because it offers more direct support to NAT, and therefore the greatest challenge to traditional notions of individual responsibility. Let us also assume that divided or diminished consciousness is more common than we think. Nevertheless, neither of these assumptions supports the more radical, general NAT thesis.

To demonstrate that divided or partial consciousness is more common than it appears certainly extends the range of cases in which people are not responsible or have diminished responsibility, but such studies do not

${ }^{281}$ See JefFrey L. Cummings \& Michael S. MEga, Neurospsychiatry and BEHAVIORAL NEUROSCIENCE 333-43 (2003) (description of dissociative and related states and their causes and treatments); D. Vaitl et al., Psychobiology of Altered States of Consciousness, 131 PsYchOL. BuLl. 98 (2005).

${ }^{282}$ See supra notes 58-66 and accompanying text. 
demonstrate that most human bodily movements that appear intentional and rational occur when the person has altered consciousness. One cannot generalize to all human behavior from genuinely deviant cases or cases in which a known abnormality is present. A model of action (or, we should say, non-action) built on sleepwalking, for example, is hardly a threat to orthodox notions of individual responsibility.

There is substantial empirical evidence to suggest that experimental laboratory manipulations of unsuspecting subjects can cause the subjects to believe that their intentions were producing action when this was not the case. ${ }^{283}$ That subjects can be cleverly misled to misunderstand the causal role of their intentionality by experimental manipulations hardly indicates that intentions generally play no role in explaining our behavior. The brain and other material variables may cause our behavior, but not because such variables are intentional manipulators. ${ }^{284}$

Finally, there is accumulating evidence that various psychological processes have their biological substrates in localized regions of the brain. We have long known that many behavioral activities were biologically based in highly specific regions. For example, specific areas in the brain are necessary to produce expressive speech fully. If they are lesioned, the subject becomes aphasic and will not be able to produce more than simple sentences. ${ }^{285}$ For another example, the ability to recognize faces is highly localized in a region of the temporal lobe of the right hemisphere referred to as the "fusiform face area." In the unusual cases in which this area is lesioned, the subject loses the ability to recognize faces, a condition called prosopagnosia. ${ }^{286}$ Now, however, functional neuroimaging techniques that permit the exploration of brain activity during more complicated psychological processes can identify biological substrates for such processes. For example, specific brain regions are associated with decisions to purchase an object. ${ }^{287}$ For another example, a recent study demonstrated that investigators could determine from the region of brain

283 See John A. Bargh, Bypassing the Will: Toward Demystifying the Nonconscious Control of Social Behavior, in THE NEw UNCONSCIOUS, supra note 271, at 37 (reviewing the evidence and concluding that the "will" is not primarily responsible for action).

284 Daniel C. DennetT, Elbow RoOM: The Varieties of Free Will Worth Wanting 8-9 (1984) (explaining in the related context of the determinist critique that determinism does not mean that a "nefarious neurosurgeon" is controlling your behavior).

285 ANNA BASSO, APAHASIA AND ITS THERAPY 30-31 (2003).

286 James W. Tanaka, Object Categorization, Expertise, and Neural Plasticity, in THE Cognitive Neurosciences III 877, 883 (Michael S. Gazzaniga ed., MIT Press 3d ed. 2004).

287 See Knutson et al., supra note 268. 
activity which activity-adding or subtracting-a subject had covertly intended to perform but had not yet performed. ${ }^{288}$

The localization evidence is immensely interesting and suggestive, but none of it indicates that mental states play no role in causally explaining behavior. There must be a biological substrate in the brain for all human behavior. If your brain is dead, you are dead and not behaving at all. Nor is it surprising that particular regions of the brain are associated with particular psychological processes. For example, a leading, albeit controversial, theory of how the mind works suggests that it is composed of different systems that perform different functions. ${ }^{289}$ Although we do not know how the brain enables the mind, it makes sense to assume that specific psychological processes would have brain substrates specific to the process in question. Based on what we already knew about localization and based on the entirely reasonable assumption that it would be inefficient if all regions of the brain needed to be equally activated to support any psychological process, localization is most likely to be true generally. Even if all this is true, however, it does not follow that mental states do no causal explanatory work. It demonstrates at most that the neural network substrates for specific mental functions may be localizable to specific regions of the brain.

What is needed to support NAT is a general demonstration that causal intentionality is an illusion, but no such general demonstration has yet been produced by scientific study. The most interesting evidence has arisen from studies done by neuroscientist Benjamin Libet, ${ }^{290}$ which have generated an immense amount of comment. ${ }^{291}$ Indeed, many claim that Libet's work is

288 John-Dylan Haynes et al., Reading Hidden Intentions in the Human Brain, 17 CURRENT BIOLOGY 323 (2007). It is important to recognize that the brain activity accurately predicted only which type of process the subject had covertly formed the intention to perform. It did not identify the specific content of the intention, such as which two numbers the subject intended to add or subtract. Despite the enormous advances in cognitive neuroscience, we do not know how to read minds using neuroimaging or any other technique. Cf. Martha J. Farah, Bioethical Issues in the Cognitive Sciences, in THE Cognitive Neurosciences III, supra note 286 , at $1309-10$ (referring to the ability to identify traits and states as "a crude form of mindreading").

${ }^{289}$ E.g., JERRY FODOR, THE MODULARITY OF MIND (1983) (providing a strict modular theory).

290 Benjamin Libet, Do We Have Free Will, in The Volitional Brain: Towards a NeUROSCIENCE OF FreE WILl 47 (Benjamin Libet et al. eds., 1999) (summarizing the findings and speculating about their implications).

${ }^{291}$ WEGNER, supra note 269, at 54-55 (characterizing the recounting of Libet's results as a "cottage industry" and noting the large and contentious body of commentary). 
the first direct neurophysiological evidence of NAT. ${ }^{292}$ Libet's exceptionally creative and careful studies demonstrate that measurable electrical brain activity associated with intentional actions occurs in the relevant motor areas of the brain about 550 milliseconds before the subject actually acts and about $350-400$ milliseconds before the subject is consciously aware of the intention to act.

Let us assume, with cautious reservations, ${ }^{293}$ the validity of these studies. The crucial question then becomes whether the interpretation of these findings as supporting NAT is valid. It does not follow from this temporal ordering that conscious intentionality does no causal work. It simply demonstrates that non-conscious brain events precede conscious experience. Although we have no idea how the brain enables the mind, this seems precisely what one would expect of the mind-brain. All psychological processes, including conscious intentionality, must begin with brain activity because the mind is realized in the brain. Electrical impulses move quickly along neural pathways, but some lag between brain activity and conscious experience seems unsurprising. Electrical activity in the brain is precisely that: electrical activity in the brain and not a mental state such as a decision or intention. A readiness potential is not a decision. Prior electrical activity does not mean that conscious intentionality played no causal role.

Libet does not carefully distinguish between urges or wants on the one hand and decisions and intentions on the other. ${ }^{294}$ Indeed, Alfred Mele argues that the experimental evidence is much more consistent with a readiness potential being associated with an urge rather than with an intention or decision. ${ }^{295}$ A perfectly plausible reading of Libet's work is that various non-conscious causal variables, including non-conscious urges, precede action, but that intentionality is nonetheless necessary for action.

Libet also claims that subjects can "veto" the act during the delay between becoming aware of the intention and performing the intended action. He surprisingly conceives of this "veto" as an undetermined act. Other researchers appear to have localized the part of the brain that is the

${ }^{292}$ William P. Banks \& Susan Pockett, Benjamin Libet's Work on the Neuroscience of Free Will, in The BlackWell COMPANION to CONSCIOUSNESS 657, 658 (Max Velmans \& Susan Schneider eds., 2007).

${ }^{293}$ E.g., Henrik Walter, Neurophilosophy of Free Will: From Libertarian ILLUSIONS TO A CONCEPT OF NEURAL ANATOMY 250-52 (Cynthia Klor trans., 2001) (2001); Jing Zhu, Reclaiming Volition: An Alternative Interpretation of Libet's Experiment, $10 \mathrm{~J}$. CONSCIOUSNESS STUD. 61 (2003).

${ }^{294}$ AlFred R. MELE, FREe WILl AND LUCK 33 (2006); see also M.R. BENNETT \& P.M.S. HACKer, PHILOSOPHICAL FoundatIoNS OF NEUROSCIENCE 228-31 (2003) (criticizing Libet's account of action).

${ }^{295}$ MELE, supra note 294, at 33, 40. 
substrate for this activity of vetoing. ${ }^{296}$ In addition to the implausibility of the veto being undetermined, ${ }^{297}$ the conceptual foundation of the interpretation that the subjects were exercising a genuine veto is shaky at best. ${ }^{298}$ This suggestion of an undetermined veto undermines the claim that the brain is doing all the work because it is apparently a newly formed intention to veto that causes the agent not to perform the act. In short, Libet's work presupposes agency at every step in the process.

Finally, Libet's task involved "random" finger movements that involved no deliberation whatsoever and no rational motivation for the specific movements involved. ${ }^{299}$ This is a far cry from the type of intentional conduct that is the criminal law's concern. The commands of the criminal law address intentional actions or omissions in contexts in which there is always good reason to refrain from harming another or to act beneficently. At present, it is an open question whether Libet's paradigm is representative of intentional action in general because the experiments involved such trivial behavior. ${ }^{300}$

Libet's work is fascinating, but it does not provide a general proof that humans are never or infrequently conscious, intentional agents, or that they are not capable of employing their conscious intentionality when they have good reason to do so, or that these intentions play no causal role. ${ }^{301}$ Even if Libet's work is methodologically valid, as we have assumed, various conceptual and interpretive arguments massively undermine the claim that Libet has demonstrated that NAT is true.

Moreover, NAT provides no guidance about what we should do next and, in any event, degenerates into a self-referential incoherence. Let us suppose that you were convinced by the mechanistic view that you were not an intentional, rational agent after all. (Of course, the notion of being convinced would be an illusion, too.) What should you do now? You know it is an illusion to think that your deliberations and intentions have any causal efficacy in the world. You also know, however, that you experience sensations such as pleasure and pain and that you care about what happens to you and to the world. You cannot just sit quietly and wait

${ }^{296}$ Marcel Brass \& Patrick Haggard, To Do or Not to Do: The Neural Signature of SelfControl, 27 J. NEUROSCIENCE 9141, 9141-45 (2007).

${ }^{297}$ Banks \& Pockett, supra note 292, at 667.

${ }^{298}$ MELE, supra note 294, at 34-35.

299 Participating in the study and cooperating with the investigator can be rationally motivated, of course. But the experimental task was to move one's finger randomly and thus for no good reason.

300 Banks \& Pockett, supra note 292, at 662-63.

301 See Jerry Fodor, Making the Connection, Times Literary Supplement, May 17, 2002 , at 4 (arguing that the new neuroscience rarely has much to contribute when the phenomenon in question is complex social behavior). 
for your neurotransmitters to fire. You must and will, of course, deliberate and act.

That is, even if pure mechanism is true-about which, once again, we will never be certain until we solve the mind-body problem-human beings will find it almost impossible not to treat themselves as rational, intentional agents unless there are major changes in the way our brains work. Indeed, as we discuss below, there are powerful evolutionary explanations for the causal efficacy of our mental states, states that are the predicates for responsibility. ${ }^{302}$ Overcoming what may in fact be neuro-architectural facts of evolution may be only a little less likely than "overcoming" our opposable thumbs. ${ }^{303}$ Moreover, as we saw, if you use the truth of pure mechanism as a premise in deciding what to do, this premise will entail no particular moral, legal, or political conclusions. It will provide no guide to how one should live, including how one should respond to the truth of NAT.

Finally, the argument from common sense in favor of the justified belief that we are conscious, intentional creatures is overwhelming. Consider again, for example, the nature of law itself. As we have seen, law is a system of rules that at the least is meant to guide or influence behavior and thus to operate as a potential cause of behavior. It would be impossible at present for us to abandon the well-justified belief that action may be influenced by reason and that our intentions are causally efficacious. As the eminent philosopher of mind Jerry Fodor wrote:

[I]f commonsense intentional psychology were really to collapse, that would be, beyond comparison, the greatest intellectual catastrophe in the history of our species; if we're that wrong about the mind, then that's the wrongest we've ever been about anything. The collapse of the supernatural, for example, doesn't compare .... Nothing except, perhaps, our commonsense physics ... comes as near our cognitive core as intentional explanation does. We'll be in deep, deep trouble if we have to give it up .... But be of good cheer; everything is going to be all right. ${ }^{304}$

The new neuroscience does not pose, and is unlikely ever to pose, a real threat to our fundamental conception of personhood and all that follows from it, including the concept of responsibility and related concepts, such as

302 See infra text accompanying note 306.

${ }^{303}$ See infra text accompanying note 311 .

304 Jerry Fodor, PSychosemantics: The Problem of MEANING IN the Philosophy of MIND xii (1987). The entire book is a defense of common sense intentional explanation. See generally BERTRAM F. MALlE, How the Mind EXPlains BEHAVIOR: FolK EXPLANATIONS, MEANING AND SOCIAL INTERACTION (2004) (providing a full theoretical account and empirical support). There is also growing recognition within psychology that "mental state inference is one of the most fundamental tools of social cognition." Bertram F. Malle, Folk Theory of Mind: Conceptual Foundations of Human Cognition, in THE NEW UNCONSCIOUS, supra note 271 , at $225,229$. 
mens rea. At the very least, we remain entitled to presume that conscious intentions are potentially rational and causal and to place the burden of persuasion at a very high level on proponents of NAT. At present, the case is not close to meeting the burden. We are fully entitled to continue to believe that we are the sorts of creatures we believe ourselves to be.

\section{B. THE ROOTS OF RESPONSIBILITY}

If the sciences have not yet shown that individual responsibility is an unjustified illusion, where does it come from? Might those roots provide a useful guide to what the criteria should be for holding each other responsible? In this Part, we consider newer philosophical and neuroscientific approaches to this age-old question.

One of the most influential modern philosophical theories of responsibility, beginning with a classic article by P.F. Strawson ${ }^{305}$ and expanded by many others, ${ }^{306}$ argues that responsibility is rooted in our reactive emotions, such as indignation, resentment, anger, and gratitude. When we are benefited or harmed by compliance with or breach of a normative obligation, we tend to have such reactive emotions. Nonetheless, we think that such reactions are justified only if the agent acted with the right mental state and was responsible. If the agent was not responsible, we may continue to have a reactive emotion, but on reflection would concede that it is not justified. Further, if we think that our reactive attitude is justified, we also think that we are justified in expressing that attitude in an appropriate way. This process can occur publicly or privately, as personal moral criticism or criminal law blame and punishment, for example. To hold someone responsible, then, is to believe that one is justified in having and expressing a reactive attitude. In criminal responsibility terms, holding responsible means that we believe we are justified in blaming and punishing wrongdoers. Blaming in this context means more than simply grading. It refers to a moral evaluation of the criminal's conduct. ${ }^{307}$

Although the content of the normative obligations and the specific reactive emotions and expressions might vary temporally or culturally, it is probably true that all cultures have responsibility practices that bear some resemblance to this account. It is certainly the case in Western systems of morality and law. It is also striking that there is enormous agreement, including cross-culturally, about the rank ordering of the seriousness of the

305 P.F. Strawson, Freedom and Resentment, in FREE WILL 59 (Gary Watson ed., 1982).

${ }^{306}$ See, e.g., R. JAY WALLACE, RESPONSIBILITY AND THE MORAL SENTIMENTS (1994).

307 HILARY BOK, FREEDOM AND RESPONSIBILITY 35-39 (1998). 
harms to persons and property that are at the core of the criminal law, ${ }^{308}$ although much less agreement about the appropriate penalty structure.

There is a deep explanation of the ubiquity of the reactive emotions themselves that is coming primarily from the sciences-from evolutionary biology, evolutionary psychology and, indeed, even from neuroscience itself. In fact, Strawson predicted some of these results, asserting that the reactive attitudes were part of human nature, and that it would be impossible to obliterate them, and undesirable to do so even if we somehow could. $^{309}$ Having biological roots of course does not guarantee that a practice is normatively desirable. ${ }^{310}$ To believe otherwise is the naturalistic fallacy, but if a practice has biological roots, biology can indicate the "price" for abandoning it.

Evolutionary theorists have demonstrated with game-theoretic precision that many otherwise confounding animal behaviors, including some human behaviors, are perfectly adaptive; they are widespread because they provided individual actors with survival advantage, reproductive advantage, or both. ${ }^{311}$ It is now settled that all animals, including humans, have evolved tendencies to act in certain predictable ways under certain conditions.

We believe that this sort of evolutionary account is the best explanation of the ubiquity of reactive responsibility practices and of the powerful agreement about ordinal harm rankings. There is good experimental evidence to suggest, for example, that homo sapiens are predisposed to be altruistic retributivists. ${ }^{312}$ A more recent experimental

${ }^{308}$ Paul H. Robinson \& Robert Kurzban, Concordance \& Conflict in Intuitions of Justice, 91 MinN. L. REv. 1829 (2007) (people's intuitions of justice concerning the core harms of the criminal law are specific, nuanced, and widely shared cross-culturally).

309 See also P.F. STRAwSON, SKEPTICISM AND NATURALISM: SOME VARIETIES 35-37 (1983). Later commentators have differed about a seemingly naturalized account of the reactive emotions theory of responsibility. Compare GEORGE SHER, IN PRAISE OF BLAME 1 (2005) (criticizing Strawson), with Andrew Oldenquist, An Explanation of Retribution, 85 J. PHIL. 464 (1988) (arguing for a naturalized account of retribution).

310 See BOK, supra note 307 , at 26-27.

${ }^{311}$ See, e.g., W.D. Hamilton, The Genetical Evolution of Social Behavior, 7 J. THEORETICAL BIOLOGY 1, 1-52 (1964); Robert L. Trivers, The Evolution of Reciprocal Altruism, 46 Q. REv. BIOL., Mar. 1971, at 35-37 (1971).

312 See Ernst Fehr \& Simon Gächter, Altruistic Punishment in Humans, 415 NATURE 137, 137 (2002) (finding that experimental evidence suggests human beings have evolved to engage in nonutilitarian, "altruistic" punishment when members of their social group "defect" by violating a normative expectation). More recent, consistent evidence suggests that, at least in men (who do most of the punishing for free riding), empathic responses are shaped positively by fair treatment by others and negatively by unfair treatment. Tania Singer et al., Empathic Neural Responses Are Modulated by the Perceived Fairness of Others, 439 NATURE 466 (2006). Other cooperative primates exhibit behavior best interpreted as expressing resentment when they perceive that they are treated undeservedly 
study demonstrates that societies with an altruistic punishment mechanism have a competitive advantage compared with a rival society without one. Although subjects initially prefer the society without punishment, they quickly migrate to the sanctioning society because greater social cooperation occurs in the latter. ${ }^{313}$ All these findings are consistent with an evolutionary account of how successful human societies enforced cooperation by their response to free riding. ${ }^{314}$

Punishing free-riders is only part of the evolutionary story. We have adaptive proclivities to free-ride, but we also have adaptive proclivities to cooperate. As a profoundly social species, it takes no great leap of imagination to understand that our ancestors would have been much less successful, and therefore much less likely to be our ancestors, if they were unable to understand the intentions of others, not sure they could convert their intentions into action, and not equipped with powerful assumptions that that stranger coming over the hill is equipped with the same capacity for harmful intentions as they are. ${ }^{315}$ Moreover, evolution has equipped us with an advanced and sensitive system to modulate short-term individual benefits (steal that car) against long-term individual costs (go to prison), and vice versa. They are two sides of the same evolutionary coin, and, inflamed with that sometimes cursed and almost-ever-present consciousness, they are the heart of the human dilemma and at the heart of law and morality.

Of course, holding people responsible and giving them their just deserts is clearly a complex social practice that is inevitably and powerfully affected by culture and individual learning and socialization. Blaming and

unequally. See Sarah F. Brosnan \& Frans B.M. de Waal, Monkeys Reject Unequal Pay, 425 NATURE 297, 297 (2003); see generally PAUL W. GlimCHER, Decisions, UnCERTAINTY AND THE BRAIN: THE SCIENCE OF NEUROECONOMICS (2003).

${ }^{313}$ Ozgur Gurerk, Bernd Irlenbusch \& Bettina Rockenbach, The Competitive Advantage of Sanctioning Institutions, 312 SCIENCE 108 (2006).

314 David M. Buss, Evolutionary Psychology: The New SCIENCE of THE Mind 27677 (2d ed. 2004); Steven Pinker, The Blank Slate: The Modern Denial of Human NATURE 180-82 (2002). Indeed, that irrepressible sense of freedom of action and "personhood" that we have already discussed in philosophical and legal contexts is most likely irrepressible because our brains evolved to experience and construct that sense of freedom and personhood. See, e.g., Morris B. Hoffman \& Timothy H. Goldsmith, The Biological Roots of Punishment, 1 OHIO ST. J. CRIM. L. 627 (2004).

${ }^{315}$ See Justin N. Wood et al., The Perception of Rational, Goal-Directed Action in Nonhuman Primates, 317 SCIENCE 1402, 1405 (2007) (demonstrating that the ability to understand the intentions of other creatures evolved in primates 40 million years ago); see also Esther Herrmann et al., Humans Have Developed Specialized Skills of Social Cognition: The Cultural Intelligence Hypothesis, 317 SCIENCE 1360 (2007) (comparing chimpanzees and orangutans to two-and-a-half-year-old humans and discovering that they have approximately equal cognitive skills concerning the physical world, but that humans have superior cognitive skills for understanding social interaction). 
punishing are not solely the product of our DNA or our neuro-architecture. There is no single punishment gene or neural network. Nonetheless, we seem strongly predisposed to feel and to express retributive sentiments, a predisposition that might not be so easy to overcome, even it were normatively a good idea to do so.

As we have suggested previously, holding certain people responsible and excusing others is profoundly normatively desirable. It takes people seriously as potentially moral agents and contributes to human dignity and respect. It also facilitates social cooperation. We would be giving up much that is worthwhile if we abandoned the practice of responsibility merely to be consistent with an allegedly clear-eyed and scientific view that no one should be blamed and punished and that we should be concerned solely with the consequences of social control. An irrationality excuse, like the insanity defense, may ultimately not be of much benefit in terms of social safety, but it is crucial to taking responsibility seriously.

\section{MENS REA, LEgAL INSANITY, AND COMMON SENSE}

The moral (pardon the expression) of our story is that the criminal law must continue to emphasize the importance of mens rea and rationality, and that deciding whether a defendant lacks mens rea or is sufficiently irrational to be excused are factual and moral decisions that may safely be left to the common sense of ordinary people.

There will still be interpretive questions, of course. Consider the following cases of potential legal insanity:

(1) The delusional self-defender who actually believes that he is in imminent wrongful danger of death.

(2) Daniel M'Naghten, who is equally deluded about the danger to his life, but does not believe that his death is imminently threatened by the victim.

(3) A person who hallucinates that she heard God's voice command her to kill her children and delusionally believes that she must obey in order to produce eternal peace on earth.

(4) Andrea Yates, who believes that she must kill her children now to save them from Satan's eternal torments.

(5) A person who delusionally believes his spouse is unfaithful despite having no objective evidence of this whatsoever and kills her in a state of jealous rage sparked by his delusional belief.

(6) The psychopath: a person who knows what he is doing and knows the "prices," such as going to prison, for failing to comply with certain rules, but who entirely lacks conscience and empathy and does not get the point of morality or its rules at all. 
The first five defendants are equally deluded and equally irrational, but all meet the elements of the prima facie case because all are at least arguably capable of forming the required mens rea. The psychopath clearly has no problem forming mens rea, so only legal insanity is in question. Yet there is no obvious right answer to these cases under any insanity defense rule. Indeed, the authors of this paper disagree about some of them.

If the question is simply whether the practical reason resulting in the crime was substantially affected by irrationality, then the first five should all be acquitted by reason of insanity. The case of the delusionally jealous person is arguably distinguishable because no plausible theory of justification or mitigation would apply even if the facts were true. There is some merit to this distinction (and most insanity tests would not acquit this defendant), but it is not self-evident. After all, the fundamental premise of the agent's practical reason was delusional and uncorrectable. Quite simply, the agent is not rational even though his general moral compass may be intact. One might well want to acquit such a person.

Indeed, the Privy Council recently decided a case involving a structurally similar set of facts. ${ }^{316}$ Defendants were Rastafarians who entered a Roman Catholic church on Santa Lucia, attacked the congregants, tried to burn the church and churchgoers, and killed a nun and the priest who had intervened. ${ }^{317}$ Defendants claimed they acted in response to their Rastafarian beliefs and to hearing voices, and that the attack was politically motivated. ${ }^{318}$ Expert evidence suggested that although Rastafarian beliefs are hostile to Roman Catholicism, these defendants were delusional. ${ }^{319}$

The question on appeal was how properly to construe the Santa Lucia Criminal Code's insanity provisions. ${ }^{320}$ The insanity defense had two prongs. The first was a standard M'Naghten rule. The second excused the defendant:

[I] $\mathrm{f}$ he did the act ... under the influence of a delusion of such a nature as to render him, in the opinion of the jury or of the Court, an unfit subject for punishment of any kind in respect of such act. ${ }^{32}$

The issue was whether the second prong was an independent test or whether the delusional state had to satisfy the standard strictures of M'Naghten. ${ }^{322}$ The defendants clearly knew in a narrow sense what they

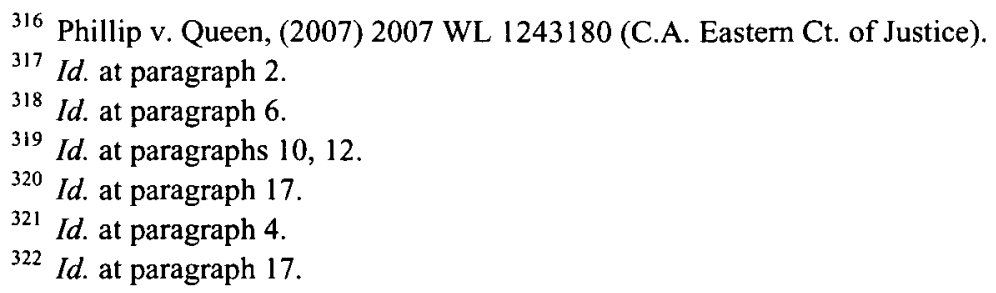


were doing and knew it was unlawful; they would not have been justified even if the dreadful social conditions that motivated them were true. Thus, unless a sufficient delusion alone would be reason to acquit, they had to be convicted. ${ }^{323}$

The Privy Council decided on both historical and normative grounds that the delusional prong was an independent test that was meant to broaden the insanity defense beyond M'Naghten's bounds. ${ }^{324}$ Conceding that it was difficult to determine when a delusion alone would render a defendant unfit for punishment, it suggested that if a defendant were impelled or persuaded by delusional beliefs to commit deeds he knew were forbidden, then deterrence would fail and "the object of retribution would be repugnant to the conscience of the ordinary citizen." ${ }^{\prime 325}$ In short, the Privy Council accepted an expansive reading of the Santa Lucia statute that permitted acquittal by reason if insanity if the defendant's rationality were sufficiently undermined by mental abnormality, even if the defendant knew what he was doing and knew that it was wrong. Whether this result is morally and socially desirable is open to debate, but it is a merciful standard that is morally, intellectually, and socially plausible. ${ }^{326}$

Suppose, instead, the test is whether the defendant acted for a good justifying reason under positive law if the deluded reasons were true. ${ }^{327}$ Even then, some of these cases are close, including (3) and (4). In the latter, would the general justification of necessity or "balance of evils" apply if the belief were true? Is this even a sensible way to put the question? Finally, disposition of the sixth case depends entirely on how one defines rationality for purposes of ascribing responsibility. These are people who know what they are doing and know the rules but who simply do not understand the difference between good and evil. Are they irrational or simply bad?

In the end, reasonably crafted definitions of mens rea and insanity, coupled with the common sense of jurors, should be sufficient to create systems of responsibility robust enough to reflect a strong presumption of blameworthiness, yet sensitive enough to recognize the rare exception.

${ }^{323}$ The defendants in Phillip were not morally identical to the delusionally jealous killer because the former thought they were politically and morally justified. Nevertheless, in neither case would the defendants be acquitted if the facts they believed were true.

324 Id. at paragraph 21.

325 Id. at paragraph 24.

${ }^{326}$ Author Morse is attracted to but ambivalent about this test. See Morse, supra note 247. Author Hoffman agrees that it is plausible, but believes it is a dreadful test.

${ }^{327}$ This alternative is quite akin to the "justification" part of the integrationist approach discussed supra at note 250 and accompanying text, but in this case the excuse is explicitly tied to the agent's irrationality and no general subjectivization of justifications is necessary. 
Indeed, jurors alone, with available information concerning mens rea and excusing doctrines but with no other guidance about the details of those doctrines seem perfectly competent to make such judgments. ${ }^{328}$

There is good evidence to suggest that the language of the insanity defense does not make a great deal of difference to the outcome of insanity cases. ${ }^{329}$ Jurors apparently reach a rather "rough and ready" judgment about which offenders deserve to be excused. Not surprisingly, the major variable that affects the outcome is the severity of the offender's disorderthat is, how grossly out of touch with reality the defendant was. ${ }^{330}$ Nonpsychotic offenders seldom succeed, which is the intuitive moral result, since, as we have discussed, most non-psychotic people are not sufficiently irrational to deserve an excuse. ${ }^{331}$

In sum, we can apparently trust the good judgment of juries in most insanity cases. We cannot and should not expect more.

\section{CONCLUSION}

Clark reached the right result on legal insanity but the wrong result on mens rea, and, in doing so, perpetuated the blurring of the two. Stout, but clearly separate, doctrines of intentionality and excuse will help jurors use their common sense about both. That will in turn help ensure results that mesh with our most fundamental notions of individual responsibility and blameworthiness. For now, desirable concepts of responsibility and blame are not undermined by the newest scientific findings about behavior.

${ }^{328}$ Rita J. Simon \& David E. Aaronson, The InSANity Defense: A Critical Assessment of LAW AND POLICY IN THE POST-HINCKLEY ERA 113-35 (1988) (jurors could fairly and sensibly apply the law).

329 Henry M. STEAdman ET Al., Before and After HinCKLEY: Evaluating InSANity DEFENSE REFORM 61-62 (1993). Changes in the burden of persuasion were more effective. Id. at $142-43$.

$330 I d$. at 31 .

331 There is great behavioral heterogeneity among people with psychotic disorders, so not all of them should be excused, even if their psychotic processes played a role in their practical reason. DSM-IV-TR, supra note 50, at xxix. 
